University of Nebraska - Lincoln

DigitalCommons@University of Nebraska - Lincoln

Papers in the Earth and Atmospheric Sciences

Earth and Atmospheric Sciences, Department

\title{
Paleolimnological evidence of the effects on lakes of energy and mass transfer from climate and humans
}

\author{
Peter R. Leavitt \\ University of Regina, Peter.Leavitt@uregina.ca \\ Sherilyn C. Fritz \\ University of Nebraska-Lincoln, sfritz2@unl.edu \\ N. J. Anderson \\ Loughborough University, N.J.Anderson@lboro.ac.uk \\ P. A. Baker \\ Duke University, pbaker@duke.edu \\ T. Blenckner \\ Uppsala University, Norrtälje, Sweden
}

See next page for additional authors

Follow this and additional works at: https://digitalcommons.unl.edu/geosciencefacpub

Part of the Earth Sciences Commons

Leavitt, Peter R.; Fritz, Sherilyn C.; Anderson, N. J.; Baker, P. A.; Blenckner, T.; Bunting, L.; Catalan, J.; Conley, D. J.; Hobbs, W. O.; Jeppesen, E.; Korhola, A.; McGowan, S.; Rühland, K.; Rusak, J. A.; Simpson, G. L.; Solovieva, N.; and Werne, J., "Paleolimnological evidence of the effects on lakes of energy and mass transfer from climate and humans" (2009). Papers in the Earth and Atmospheric Sciences. 121. https://digitalcommons.unl.edu/geosciencefacpub/121

This Article is brought to you for free and open access by the Earth and Atmospheric Sciences, Department of at DigitalCommons@University of Nebraska - Lincoln. It has been accepted for inclusion in Papers in the Earth and Atmospheric Sciences by an authorized administrator of DigitalCommons@University of Nebraska - Lincoln. 


\section{Authors}

Peter R. Leavitt, Sherilyn C. Fritz, N. J. Anderson, P. A. Baker, T. Blenckner, L. Bunting, J. Catalan, D. J.

Conley, W. O. Hobbs, E. Jeppesen, A. Korhola, S. McGowan, K. Rühland, J. A. Rusak, G. L. Simpson, N.

Solovieva, and J. Werne 


\title{
Paleolimnological evidence of the effects on lakes of energy and mass transfer from climate and humans
}

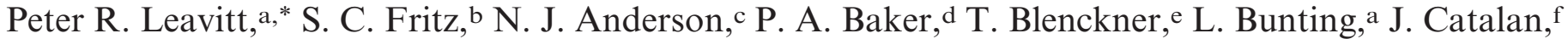

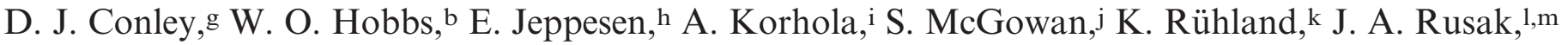 \\ G. L. Simpson, ${ }^{n}$ N. Solovieva, ${ }^{n}$ and J. Werneo
}

a Limnology Laboratory, Department of Biology, University of Regina, Regina, Saskatchewan, Canada

b Department of Geosciences and School of Biological Sciences, University of Nebraska, Lincoln, Nebraska

c Department of Geography, Loughborough University, Loughborough, Leicestershire, United Kingdom

d Division of Earth and Ocean Sciences, Duke University, Durham, North Carolina

e Erken Laboratory, Ecology and Evolution, Evolutionary Biology Centre, Uppsala University, Norrtälje, Sweden

f Centre for Advanced Studies of Blanes, CEAB, Spanish National Research Council, CSIC, Blanes, Spain

g Department of Geology, Lund University, Lund, Sweden

h National Environmental Research Institute, Aarhus University, Silkeborg, Denmark

i Department of Biological and Environmental Sciences, University of Helsinki, Helsinki, Finland

j School of Geography, University of Nottingham, Notthingham, United Kingdom

k Department of Biology, Queen's University, Kingston, Ontario, Canada

1 Center for Limnology, University of Wisconsin-Madison, Trout Lake Field Station, Boulder Junction, Wisconsin

m Dorset Environmental Science Centre, Ontario Ministry of Natural Resources, Dorset, Ontario, Canada

n Environmental Change Research Center, Department of Geography, University College London, London, United Kingdom

o Large Lakes Observatory, University of Minnesota-Duluth, Duluth, Minnesota

\begin{abstract}
The premise of this article is that climate effects on lakes can be quantified most effectively by the integration of process-oriented limnological studies with paleolimnological research, particularly when both disciplines operate within a common conceptual framework. To this end, the energy (E)-mass $(m)$ flux framework (Em flux) is developed and applied to selected retrospective studies to demonstrate that climate variability regulates lake structure and function over diverse temporal and spatial scales through four main pathways: rapid direct transfer of $\mathrm{E}$ to the lake surface by irradiance, heat, and wind; slow indirect effects of $\mathrm{E}$ via changes in terrestrial development and subsequent $m$ subsidies to lakes; direct influx of $m$ as precipitation, particles, and solutes from the atmosphere; and indirect influx of water, suspended particles, and dissolved substances from the catchment. Sedimentary analyses are used to illustrate the unique effects of each pathway on lakes but suggest that interactions among mechanisms are complex and depend on the landscape position of lakes, catchment characteristics, the range of temporal variation of individual pathways, ontogenetic changes in lake basins, and the selective effects of humans on $m$ transfers. In particular, preliminary synthesis suggests that $m$ influx can overwhelm the direct effects of E transfer to lakes, especially when anthropogenic activities alter $m$ subsidies from catchments.
\end{abstract}

The structure and function of lake ecosystems is regulated by complex interactions among climate, humans, ecosystem morphology, and catchment characteristics, each of which varies in time and space (Schindler 2001). For example, climatic controls range from daily meteorological variations in local irradiance, temperature, and water fluxes (Keller 2007) through to large-scale interactions of the atmosphere and oceans (Trenberth and Hurrell 1994; Hurrell 1995; Mantua et al. 1997) and millennium-long changes in energy $(\mathrm{E})$ and mass $(\mathrm{m})$ flux around the planet (Williams et al. 1997; Diffenbaugh et al. 2006). Within this framework, chemical, physical, and ecological processes combine to determine the production and composition of aquatic communities, both uniquely and in consort with other mechanisms (Carpenter 1999). In addition, lakes are affected both by human disturbance of biotic communities

\footnotetext{
*Corresponding author: Peter.Leavitt@uregina.ca
}

and biogeochemical cycles (e.g., land use, urbanization, fisheries management) and by creation of novel stressors (e.g., acidic precipitation, toxicants, ozone loss). However, because these factors interact over diverse spatial and temporal scales, it is difficult to determine the relative importance of regulatory processes using only traditional site-based observation and experimentation. Instead, it is the premise of this article that the combined use of limnology and paleoecology represents the best means to quantify and scale interactions between climate and other control mechanisms and to develop a hierarchical understanding of how these regulatory processes are likely to influence lakes presently and in the future.

The main objective of this article is to illustrate how welldesigned studies of lake sediments can identify the mechanisms by which climate affects lakes as well as how climatic variability may interact with other regulatory processes over time scales inaccessible by standard limno- 
logical approaches. We intend to distinguish our approach from that of climate reconstruction (paleoclimatology) (Bradley 1999) by focusing on publications in which climate variability has been established previously and investigators have selected lakes, sedimentary variables, and analytical procedures to quantify the pathways by which climate variability is transmitted to lakes. We believe that this approach is more likely to encourage collaborations among aquatic scientists with diverse analytical and philosophical inclinations than would a comprehensive review of sedimentary studies (Battarbee 2000; Last and Smol 2001; Anderson et al. 2006) but clearly acknowledge that this selective presentation will invariably simplify the conceptual and methodological difficulties that remain in both modern and paleolimnological approaches (Keller 2007; Fritz 2008). Furthermore, by presenting select fossil studies in an explicitly mechanistic framework, we hope to illustrate to limnologists how careful selection of sites and sedimentary analyses can overcome temporal limitations of modern studies (Magnuson 1990) while demonstrating to paleolimnologists how incorporation of an explicit theoretical framework and hypothesis testing can facilitate sedimentary interpretation and better establish causal relationships (Anderson et al. 2006).

This article has three sections, each with a specific objective. In the first section, we develop a conceptual framework suitable for both neo- and paleolimnology to identify how climate variability enters lakes, briefly summarize the effects of these pathways on modern lakes, and identify research areas where fossil studies may improve our understanding of climate-lake interactions. Second, we review the paleolimnological evidence of how individual climate pathways affect the physical, chemical, and biotic characteristics of lakes. Finally, we identify how limnological and retrospective approaches need to be better integrated to meet new challenges and opportunities related to quantification of climate effects on lentic ecosystems.

\section{Lakes as integrators of energy (E) and mass $(m)$ influx}

The Em flux framework - Quantification of the unique and interactive effects of climate and other forcing agents on modern and ancient lakes is accomplished most easily using a common conceptual framework. We suggest that lakes respond to environmental and anthropogenic forcing by integrating influxes of $\mathrm{E}$ and $m$, as proposed originally by Pham et al. (2008, 2009) and developed further by Dröscher et al. (2009). General circulation models demonstrate that climate variability ultimately arises from the influx of solar E to Earth, its effects on the transfer of surface waters to the atmosphere, and changes in planetary patterns of $\mathrm{E}$ and water distribution. In the $\mathrm{E} m$ flux framework (Fig. 1), this climate variability subsequently enters lake ecosystems through diverse pathways including: rapid direct transfer of $\mathrm{E}$ to the lake's surface due to solar irradiance, atmospheric heat, and wind friction; slow indirect effects of $\mathrm{E}$ on catchment characteristics (e.g., soil and vegetation development) and subsequent terrestrial subsidies of $m$ to lakes; direct transfer of mass (precipitation, particles, solutes) from the atmosphere; and indirect

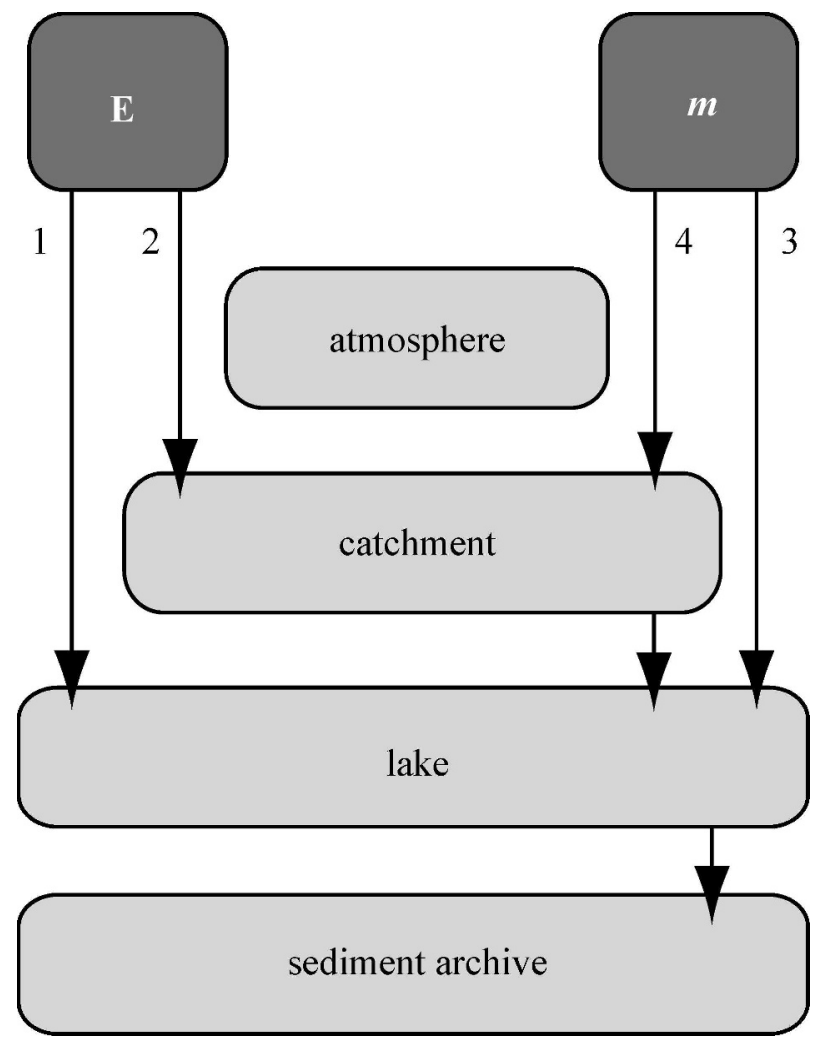

Fig. 1. Conceptual model of the pathways by which climate affects lakes, including direct influx of energy (E) to the lake (1), indirect effects of $\mathrm{E}$ on lakes via catchment processes (2), direct influx of mass $(m)$ to lake surface (3), and indirect effects of $m$ transfer via surface runoff and groundwater contributions (4). Energy can enter lakes directly as irradiance (PAR, UVR), wind friction, or transfer of atmospheric heat, while $m$ transfers includes influx of water, solutes, and particles. In the Em flux framework, the atmosphere, catchment, and lake act as information filters (Blenckner 2005) that transmit, transform, or transduce climatic variability to the sediment archive. Humans also regulate $\mathrm{E}$ and $m$ influx, mainly by altering the effects of catchment and atmospheric filters. See narrative for further description.

influx of water, suspended particles, and dissolved substances via the catchment (Table 1). As originally presented by Blenckner (2005), local variations in atmospheric and catchment features (geology, soils, vegetation, human activity) can act as information filters that alter the properties of $\mathrm{E}$ and $m$ influx as well as their effects on lakes. In addition, lakes transduce or transform historical variations in $\mathrm{E}$ and $m$ influx and ecosystem response into sedimentary time series of accumulated $m$ (Fig. 1).

Empirical observations suggest that variations in $\mathrm{E}$ and $m$ influx can have differential effects on lake structure and function. For example, limnological evidence demonstrates that $\mathrm{E}$ influx synchronizes seasonal and annual variability in physical (ice melt, thermal stratification) (Magnuson et al. 1990; Bonsal et al. 2006), chemical (salinity, ionic composition) (Pham et al. 2008, 2009), and some biological properties of lakes (Blenckner et al. 2007; Rusak et al. 2008), particularly at sites of similar basin morphology and 
Table 1. Select pathways by which climate variation alters the influx of energy (E) and mass $(m)$ into lake ecosystems. Pathways 1 to 4 refer to Fig. 1. E and $m$ may be transferred directly to a lake surface, may arrive indirectly via the catchment, and may be filtered through both atmospheric and catchment processes. Humans may directly interact with some pathways to modify the effects of climate on lakes. 1 = documented effect on pathway, $0=$ no known effect on pathway, and ? = effect unknown or poorly documented. Examples at right indicate likely source of variation in pathway, possible human effects, and select citations.

\begin{tabular}{|c|c|c|c|c|c|c|c|}
\hline Pathway & Energy & Mass & Mechanism & $\begin{array}{l}\text { Atmospheric } \\
\text { filter }\end{array}$ & $\begin{array}{l}\text { Catchment } \\
\text { filter }\end{array}$ & Humans & Examples \\
\hline $1 \mathrm{a}$ & Direct & 0 & PAR & $?$ & 0 & 0 & Planetary orbit \\
\hline $1 \mathrm{~b}$ & Direct & 0 & UVR & 1 & 0 & $1^{\mathrm{a}}$ & $\begin{array}{l}\text { Atmospheric attenuation; } \mathrm{a}=\mathrm{O}_{3} \text { depletion; } \\
\text { Hodgson et al. (2005) }\end{array}$ \\
\hline $1 \mathrm{c}$ & Direct & 0 & Wind & 1 & 0 & $1^{b}$ & $\begin{array}{l}\text { Water-column turbulence; } b=\text { deforestation; } \\
\text { Scully et al. }(2000)\end{array}$ \\
\hline $1 \mathrm{~d}$ & Direct & 0 & Heat & ? & 0 & $1^{\mathrm{c}}$ & $\begin{array}{l}\text { Atmospheric heating; } c=\text { greenhouse gas } \\
\text { accumulation; Rühland et al. (2008) }\end{array}$ \\
\hline $2 \mathrm{a}$ & Indirect & 0 & Heat & 0 & 1 & $1 \mathrm{~d}$ & $\begin{array}{l}\text { Catchment development, glaciation; } \mathrm{d}=\text { modified } \\
\text { soils, vegetation, or hydrology; Sommaruga- } \\
\text { Wograth et al. (1997); Leavitt et al. (2003) }\end{array}$ \\
\hline $3 a$ & 0 & Direct & Water & 1 & 0 & 0 & Precipitation and lake level; Aebley and Fritz (2008) \\
\hline $3 \mathrm{~b}$ & 0 & Direct & Particles & 1 & 0 & $1^{\mathrm{e}}$ & $\begin{array}{l}\text { Aoelian dust, nutrients; } \mathrm{e}=\text { land use and erosion; } \\
\text { Psenner (1999); Pulido-Villena et al. (2006) }\end{array}$ \\
\hline $3 \mathrm{c}$ & 0 & Direct & Solutes & 1 & 1 & $1^{\mathrm{f}}$ & $\begin{array}{l}\text { Atmospheric deposition of nutrients or toxicants; } \\
\mathrm{f}=\mathrm{NO}_{\mathrm{x}} \text { deposition; Battarbee et al. }(1990)\end{array}$ \\
\hline $4 a$ & 0 & Indirect & Water & 1 & 1 & $1 \mathrm{~g}$ & $\begin{array}{l}\text { Precipitation, drought, runoff; } \mathrm{g}=\text { modified soils, } \\
\text { vegetation, or hydrology; Baker et al. }(2001 a, b)\end{array}$ \\
\hline $4 \mathrm{~b}$ & 0 & Indirect & Particles & 1 & 1 & $1^{\mathrm{h}}$ & $\begin{array}{l}\text { Erosion; h = modified soils, vegetation, } \\
\text { or hydrology; Rodbell et al. (1999) }\end{array}$ \\
\hline $4 c$ & 0 & Indirect & Solutes & 1 & 1 & $1^{\mathrm{i}}$ & $\begin{array}{l}\text { Weathering; }{ }^{i}=\text { modified soils, vegetation, or } \\
\text { hydrology; Kratz et al. (1991) }\end{array}$ \\
\hline
\end{tabular}

heat capacity (Dröscher et al. 2009). Such high spatial synchrony arises because $\mathrm{E}$ transfers associated with solar and thermal influx are relatively uniform over broad geographic areas (Whitfield et al. 2002; Dröscher et al. 2009), whereas $m$ transfer associated with precipitation, runoff, and groundwater is more spatially variable (Walker et al. 1995; Quiring and Papakyriakou 2005) and reduces temporal coherence among lakes (Pham et al. 2008, 2009; Dröscher et al. 2009). Similarly, the unit effects of changes in $\mathrm{E}$ or $m$ influx (e.g., effects ${ }^{\circ} \mathrm{C}^{-1}, \mu \mathrm{g} \mathrm{P}^{-1}$, and so on) appear to be greatest when the lake content or background flux of a given factor is low, as evidenced by the disproportionate limnological effects of water heating during spring (Blenckner et al. 2007) or nutrient inputs to oligotrophic lakes (Schindler 2001). Unfortunately, relatively little is known of how $\mathrm{E}$ and $m$ fluxes interact, although comparison of whole-lake $m$ and $\mathrm{E}$ budgets suggests that energetic pathways predominate only when $m$ transfer is relatively invariant through time (Pham et al. 2008, 2009; Dröscher et al. 2009). In addition, further research is required to quantify the hierarchical regulatory relationship between indirect flux of $\mathrm{E}$ to lakes via catchments (Table 1, path 2a) and other more rapid climatic pathways.

The Em flux framework also provides an integrated conceptual platform for comparing the effects of climate and humans on lake ecosystems. For example, because human activities usually alter indirect $m$ transfer (hydrology, solute concentrations, suspended particles) rather than $\mathrm{E}$ receipt by lakes (thermal pollution), the $\mathrm{E} m$ flux framework predicts that climatic and anthropogenic forcing will interact most strongly via changes in the hydrologic characteristics of lake basins (Pham et al. 2008, 2009; Dröscher et al. 2009). Similarly, by proposing that influx be scaled as a function of lake content, this framework provides a simple metric for comparing the relative effects of $m$ and $\mathrm{E}$ transfer on aquatic ecosystems. However, despite the clear advantages of a single analytical framework, further research is required to develop the empirical and theoretical basis of the Em flux approach. In this regard, we suggest that improved understanding will arise most quickly from synthesis of process-oriented limnological studies with paleolimnological research that can integrate insights over large temporal and spatial scales.

Climate variability and role of paleolimnology - Despite a near-exponential increase in annual publications (527 in 2005) concerning climate and lakes during the past $15 \mathrm{yr}$ (three in 1990) (Thompson Reuters Web of Science 2008), there remain substantial gaps in our understanding of the mechanisms by which climate regulates lake structure and function as well as our ability to forecast the effects of climate variability in contrast to other agents of environmental change (Keller 2007). As reviewed elsewhere in this issue (Adrian et al. 2009; Tranvik et al. 2009; Schindler 2009), most limnological insights and forecasts are based on short $(<20 \mathrm{yr})$ time series that were collected for other purposes, lack a wide range in climatic and anthropogenic forcing (Magnuson 1990), and often focus on mechanisms 
that can be manipulated (e.g., temperature) rather than those that exhibit naturally high variability (e.g., precipitation). Consequently, comparatively little is known of the relative effects of individual pathways of mass (water, solutes, particulates) and energy transfer (irradiance, heat, wind), their hierarchical control relationships, or which mechanisms will predominate with future population growth and resource exploitation (Schindler 2001). In addition, forecasts of climate effects on lakes are particularly uncertain because meteorological variability during recent centuries is less than that recorded in the past (Woodhouse and Overpeck 1998) or expected during the next $100 \mathrm{yr}$ (Field et al. 2007). However, rather than being critical of limnological approaches, this article argues that the synergistic combination of a common process-oriented framework and well-designed paleolimnological analyses can improve our understanding of the temporal and spatial variability of climate effects on lakes and elucidate the hierarchical relationships among control mechanisms.

Paleolimnological analyses can provide annual-to-millennial time series of population abundance, community composition, biogeochemical processes, ecosystem subsidies, and changes in physical structure suitable for analysis of climate effects on lakes (Battarbee et al. 2005). Lakes often lie at the lowest elevation in each catchment and integrate allochthonous influxes of $m$ arising from natural and anthropogenic forcing. In general, $m$ accumulates in lake sediments in an orderly fashion according to the law of superposition (age increases with burial depth); however, changes in $\mathrm{E}$ influx can alter depositional processes and produce variations in sediment structure (lithostratigraphy), chemical characteristics (redox state of elements), and species composition (Håkanson and Jansson 1983; Smol and Cumming 2000). Although such retrospective time series can be selective or biased representations of the underlying ecological or environmental processes, these biases are often predictable (Cuddington and Leavitt 1999; Stone and Fritz 2004), and many fossil records retain the time-series characteristics of the original forcing agents (rate of change, mode of variation, diversity, baseline condition, nonlinear dynamics, thresholds, and so on). With recent advances in analytical chemistry, fossil taxonomy, and statistics (reviewed in Last and Smol 2001; Smol et al. 2001), paleolimnologists are better able to identify the causes and consequences of temporal variability arising from climate and humans. Because many ecosystem properties develop over decades to millennia because of slow variation in direct and indirect forcing mechanisms, paleoecological analyses are unique in their ability to place natural and anthropogenic disturbance into a context of baseline ecosystem variability, both through considered selection of contrasting ecosystems (e.g., deep vs. shallow lakes with common climate forcing) (Anderson et al. 2008; Keatley et al. 2008) and through state-of-the-art time-series analyses (see below).

In the next section, we use case studies as vignettes to illustrate the advantage of integrating paleolimnology into an explicitly mechanistic E $m$ flux framework while acknowledging clearly that such retrospective studies are most powerful when combined with in situ experiments, long-term monitoring, ecosystem manipulations, and modeling (Battarbee et al. 2005; Anderson et al. 2006). Detailed review of the assumptions, methodology, and limitations of lake and fossil studies is beyond the scope of this article. Instead, limnologists unfamiliar with the paleolimnological approach are referred to the monographic series Tracking Environmental Change Using Lake Sediments (Last and Smol 2001; Smol et al. 2001) as well as recent critical synopses (Battarbee 2000; Anderson et al. 2006; Fritz 2008), whereas recent limnological reviews provide sedimentary scientists with process-oriented perspectives on climate effects on modern lakes (Schindler 2001; Keller 2007; Adrian et al. 2009), the role of freshwaters in climate systems (Tranvik et al. 2009), and modeling approaches to evaluate how climate effects vary over diverse spatial and temporal scales (MacKay et al. 2009). Although the authors acknowledge that it is difficult to deduce causeand-effect relationships solely from fossil deposits (Leavitt and Hodgson 2001; Anderson et al. 2006; Fritz 2008), this article presents critical case studies to illustrate how mechanistic insights can be derived from retrospective studies. Rather than present these studies as definitive proof of the universality of identified mechanisms, we use them as clear examples and challenge all aquatic scientists to validate their applicability over a broad range of freshwater ecosystems.

\section{Fossil evidence of climate effects on lakes}

Effects of energy influx - Energy enters lakes directly by diverse mechanisms including absorbance of photosynthetically active radiation (PAR) (path 1a) and ultraviolet radiation (UVR) (path 1b), friction of wind on a lake surface (path 1c), and transfer of atmospheric heat (path 1d) (Table 1). PAR influx varies because of changes in planetary orbit that are apparent on annual, centennial, millennial, and longer time scales (e.g., Milankovitch cycles) as well as short-term changes in meteorological conditions. Unfortunately, few paleolimnological studies have attempted to evaluate the direct effects of changes in PAR influx on lake ecosystems. Instead, most mechanistic analyses to date have focused on the effects of watercolumn heating, wind-induced turbulence, and inhibitory effects of UVR. In addition, there is a vast literature illustrating how lake ontogeny varies as a function of changes in terrestrial development (soils, vegetation) arising from $\mathrm{E}$ transfer to lake catchments (Table 1, path 2a). In these cases, changes in atmospheric heat often appear to act on lakes indirectly, following transduction of $\mathrm{E}$ into terrestrial $m$ through photosynthesis and biogeochemical processes (weathering). In most instances, direct influx of $\mathrm{E}$ is affected by humans only on multidecadal time scales (via ozone, greenhouse gases, aerosols), whereas anthropogenic modification of catchments (vegetation, soils, hydrology) can rapidly modify indirect effects of $\mathrm{E}$ transfer to lakes on much shorter time scales.

Comparison of sedimentary analyses of lakes along geographic gradients demonstrates that changes in ice cover arising from transfer of atmospheric heat to lakes (Table 1, path 1d) regulate species composition of plank- 
tonic communities in undisturbed ecosystems (Rühland et al. 2008). For example, meta-analysis of fossil diatom records from over 200 lakes in the Northern Hemisphere reveals spatially structured but temporally coherent changes in species composition since the 19th century (Fig. 2), with high-latitude changes preceding alpine and temperate change by up to $100 \mathrm{yr}$ (Rühland et al. 2008). By comparing highly resolved fossil time series with 30 $100 \mathrm{yr}$ of environmental monitoring and by selecting only lakes in undisturbed catchments, the authors demonstrate that reorganization of community composition is correlated with changes in ice cover and associated limnological conditions (mixing and light regimes) rather than influx of nutrients and infer that many northern boreal lakes may have crossed an important ecological threshold as result of unprecedented atmospheric warming. In contrast, a survey of 70 montane lakes in the Canadian Rocky Mountains (Leavitt et al. 2003) reveals that variation in annual ice cover of $>100 \mathrm{~d}$ is uncorrelated $\left(r^{2}=0.00, p=1.00\right)$ with algal production estimated from fossil pigments, whereas changes in influx of dissolved organic matter (DOM) $\left(r^{2}=\right.$ $0.20, p<0.05)$ and UV radiation $\left(r^{2}=0.56, p<0.001\right)$ have strong correlations with variations in algal abundance across a treeline gradient. Because DOM stimulates algal growth both as a photoprotectant and as a nutrient in these lakes (Vinebrooke and Leavitt 1998, 2005), it is difficult to completely isolate the effects of UVR (Table 1, path $1 \mathrm{~b}$ ) from those of $m$ transfer (Table 1, path 4c). Regardless, because both surveys included the same set of alpine lakes, it can be inferred that effects of atmospheric heat transfer can be overridden in lakes experiencing a wide range of solute input (Leavitt et al. 2003 and below).

Retrospective analysis demonstrates that changes in $\mathrm{E}$ input from wind (Table 1, path 1c) can alter the physical structure, turbulent mixing, and community composition of small boreal lakes for up to $100 \mathrm{yr}$ (Fig. 3). In one study, changes in the physical structure of sediments (annual laminae) and fossil pigment composition were quantified from sediments of four lakes with different land use histories to evaluate the effects of changes in wind stress arising from forest harvest. Long Lake lies within $2 \mathrm{~km}$ of Peter, Paul, and Tuesday lakes and has similar welldocumented limnological and paleolimnological histories (Leavitt et al. 1989; Carpenter and Leavitt 1991) but contrasting exposure to forestry practices. While Long, Peter, and Paul lakes were clear-cut during the winters of 1870-1890, reference Tuesday Lake is surrounded by an extensive bog mat and has relatively little forest within in its catchment (Scully et al. 2000). However, unlike Long Lake, Peter and Paul lakes are sheltered from prevailing westerly winds by a steep moraine, whereas the two small $\left(<0.02 \mathrm{~km}^{-2}\right)$, deep $(>14 \mathrm{~m})$ stratified basins of Long Lake are located in more exposed low-lying regions (Fig. 3). Comparison of annually resolved time series from all basins shows that loss of first-growth forest from the western basin of Long Lake increased wind stress and physical mixing during fall, introduced oxygen into deep waters, eliminated anaerobic sulfur bacteria, and suppressed formation of laminated sediments from around 1875 until the 1980s. In contrast, other lakes revealed no
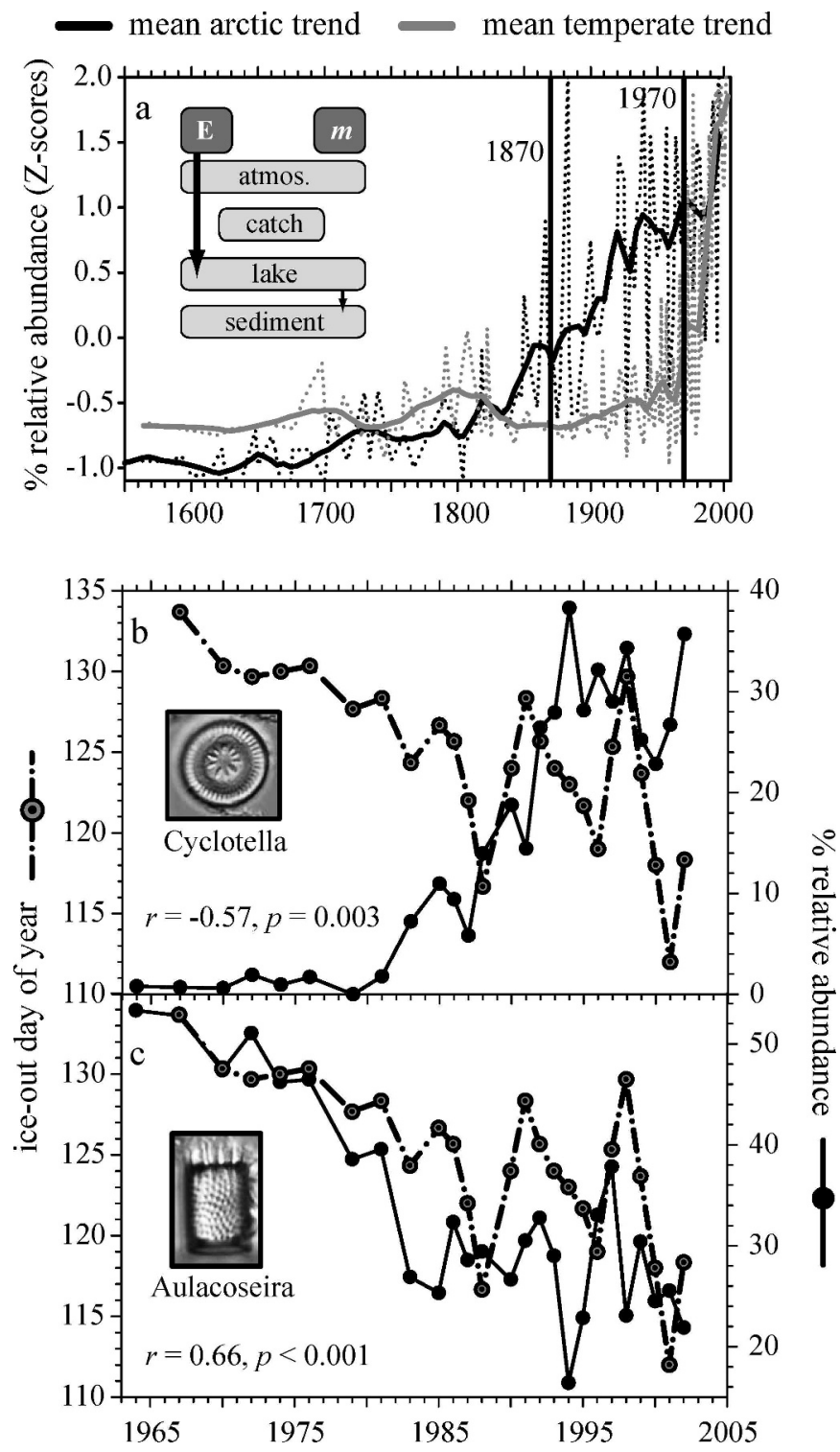

Fig. 2. Effects of direct energy (E) influx as atmospheric heat on algal community composition in 200 undisturbed Northern Hemisphere lakes (modified from Rühland et al. 2008). (a) The relative abundance of small Cyclotella spp. increases in both Arctic (black line) and temperate (gray line) lakes due to elevated $\mathrm{E}$ influx as heat, reduced ice cover, and associated limnological changes. Comparison of change in relative abundance of (b) Cyclotella and (c) Aulacoseira spp. with measured date of ice melt and nutrient influx (not shown) shows that changes in E influx (upper left inset), not mass inputs, initiate global changes in algal communities.

systematic change in sediment structure, primary production, or community composition until the occurrence of food web manipulations during the 1950s and 1980s (Leavitt et al. 1989; Carpenter and Leavitt 1991; Scully et al. 2000). Finally, the return of laminated sediments to the western basin of Long Lake around 1990 suggests that the basin is only recently returning to its preharvest $\mathrm{E}$ regime and physical structure. 
Climate-induced changes in E influx and water-column mixing (Table 1, paths 1c and 1d) can also alter species composition by restructuring aquatic biogeochemical cycles. For example, comparison of meteorological time series, sedimentary diatom records, and seasonal studies of phytoplankton composition demonstrate that changes in sedimentary diatom species composition during the 20th century (Fragilaria nanana, Cyclotella pseudostelligera) are correlated to increased temperature and water-column stability during autumn months (Sep-Oct), when these taxa predominate in algal assemblages (Catalan et al. 2002a). Changes in water-column stratification also appear to alter species composition by modifying either the seasonality or the supply ratio of potentially growthlimiting nutrients. For example, Interlandi et al. (1999) used a combination of limnological and fossil studies in lakes of the Yellowstone region of the U.S.A. to demonstrate that variations in water-column mixing altered nutrient supply to the epilimnion and directly regulated the relative abundance of spring species with high phosphorus (P) requirements (Stephanodiscus spp.) and summer taxa that require $\mathrm{N}$ (Cyclotella bodanica). These mechanistic studies were then used to interpret species changes in a detailed sedimentary sequence and suggest that seasonal variations in $\mathrm{E}$ influx, thermal stratification, and relative rates of $\mathrm{N}$ and $\mathrm{P}$ supply have been the predominant control of diatom assemblages for nearly $2000 \mathrm{yr}$ (Bracht et al. 2008). Similarly, paleoecological analysis of lakes where modern algal production is known to be fueled by $\mathrm{P}$ regeneration from the hypolimnion reveals that diatom species composition varies as a function of water-column circulation and the relative rates of supply of silica $(\mathrm{Si})$ and P (Bradbury 1988). Taken together, these studies suggest that variation in E-induced changes in nutrient biogeochemistry occur on time scales that range from seasons to millennia. However, further research is needed to better identify the unique roles of $\mathrm{E}$ influx associated with changes in irradiance, atmospheric heat, and wind.

Paleolimnological studies suggest that variation in $\mathrm{E}$ influx associated with atmospheric heating has a pronounced indirect influence on lakes (Table 1, path 2a) through long-term changes in $m$ export from terrestrial catchments (Fig. 4). For example, a combination of decade-long chemical monitoring, whole-lake ionic mass balances, analysis of diatom species composition from 57 lakes, and a 200-yr-long time series of $\mathrm{pH}$ reconstructed using standard paleolimnological techniques shows that rapid warming $\left(>2^{\circ} \mathrm{C}\right)$ since 1900 has reduced snow and ice, increased water availability, and elevated export of terrestrial sulfates into alpine lakes (Sommaruga-Wograth et al. 1997). Statistical analysis demonstrates that changes in instrumental records of air temperature are highly correlated with lake $\mathrm{pH}$ during the past two centuries $\left(r^{2}\right.$ $=0.46, p<0.001$ ), while monitoring of atmospheric deposition and mass balances eliminate changes in direct mass transfer $\left(\mathrm{H}^{+}\right.$, dust $)$as the cause of increased alkalinity. Furthermore, because availability of easily weathered substrates is highly variable among catchments, the authors conclude that such temperature-dependent mass transfer of mineral buffers is likely to induce high spatial variability in temperature effects on lakes (see below). Interestingly, the correlation between temperature and lake-water $\mathrm{pH}$ breaks down after 1900 in lakes receiving acidic precipitation (Psenner and Schmidt 1992; Psenner and Catalan 1994), suggesting that the direct influx of solutes to the lake (Table 1, path 3c) may override the indirect energetic controls of water chemistry.

Analysis of sediment cores spanning thousands of years shows that temperature change during the Holocene era can regulate lake production indirectly by altering influx of photoprotective dissolved organic matter (DOM as DOC) and overriding the inhibition of algae by UVR (Table 1, path 1b) (Fig. 5). For example, analysis of changes in algal abundance and composition, nutrients (N, P, DOC), and UVR-absorbing compounds in sediments reveals that algal biomass increases more than 10 -fold when climate warming allows soils and forests to develop at high elevation and DOM concentrations to increase sufficiently that the bottom of the lake becomes a refuge from UVR (Leavitt et al. 2003). In contrast, primary producers were suppressed up to 25 -fold during cold intervals when DOM content was $<1.5 \mathrm{mg} \mathrm{DOC} \mathrm{L}^{-1}$ and UVR penetrated throughout the lake, including the first $1000 \mathrm{yr}$ following lake formation in a variety of lentic ecosystems. Time-series analysis reveals that historical changes in algal abundance were as highly correlated to variations in UVR penetration during the Holocene $\left(r^{2}=0.55, p<0.0001\right)$, as were changes in modern algal abundance in response to UVR in surveys of mountain lakes $\left(r^{2}=0.52, p<0.001\right)$ (see above), while in both cases, variations in water-column $\mathrm{P}$ had little effect on algal abundance $\left(r^{2}\right.$ TP-algae $\left.<0.08, p \geq 0.05\right)$. Together these patterns suggest that influx of damaging UVR is capable of suppressing ecosystem production for millennia but that the inhibitory effect of $E$ influx can be overridden by thermally regulated changes in $m$ influx from land.

Analysis of past diatom communities in high latitude and recently deglaciated habitats also confirms that regional temperature change can regulate ecosystem structure by modifying the influx of organic and mineral matter from land (Table 1, path 2a). For example, changes in diatom community composition during the mid-Holocene reveal that warming increases subsidies of terrestrial DOM sufficiently that UVR intensity is reduced to below lethal levels for many aquatic organisms (Pienitz and Vincent 2000). Similar analysis of diatoms in a chronoseries of lakes in a recently deglaciated coastal landscape (Fritz et al. 2004a) refine this observation by demonstrating that, while warmer temperatures following ice melt uniformly favor development of terrestrial sources of DOM, differences in the underlying geology and subsequent edaphic development determine whether organic or inorganic subsidies can be of paramount importance in regulating algal composition.

Analysis of sedimentary deposits from waterbodies lacking terrestrial DOM sources suggest that UVR influx (Table 1, path 1b) can be a paramount control of algal production and community composition for over $100,000 \mathrm{yr}$ (Hodgson et al. 2005). Here limnological surveys of algal assemblages and surficial sediments have been used to demonstrate that benthic cyanobacteria 


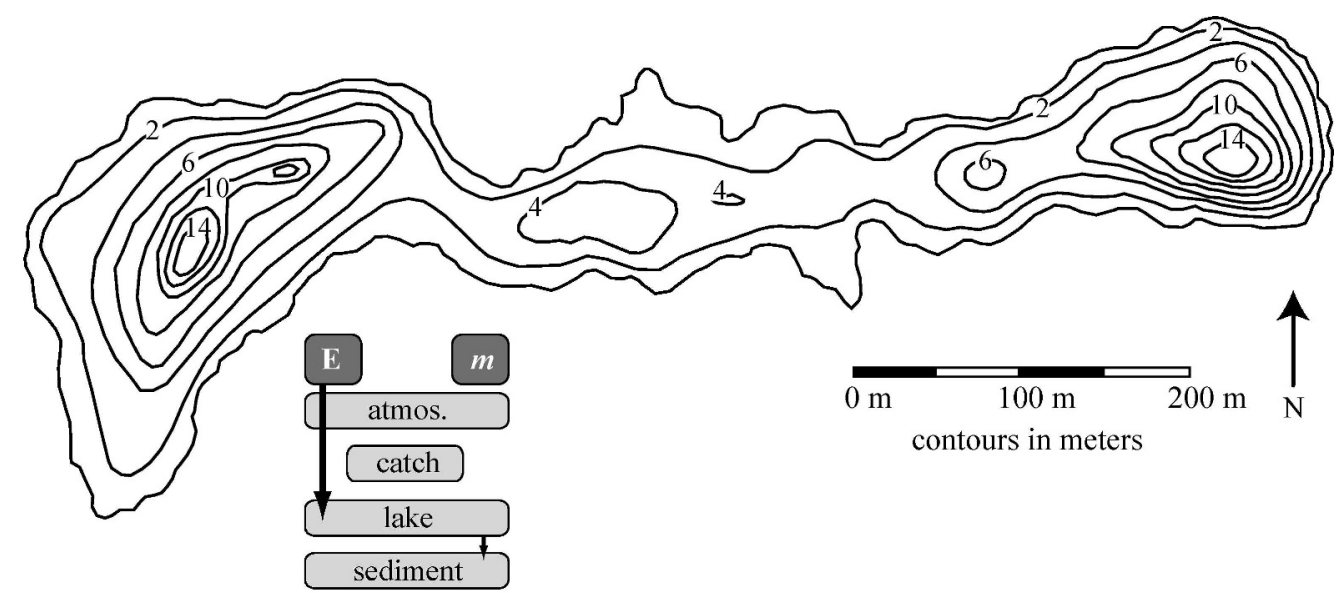

all algae ( $\beta$-carotene)
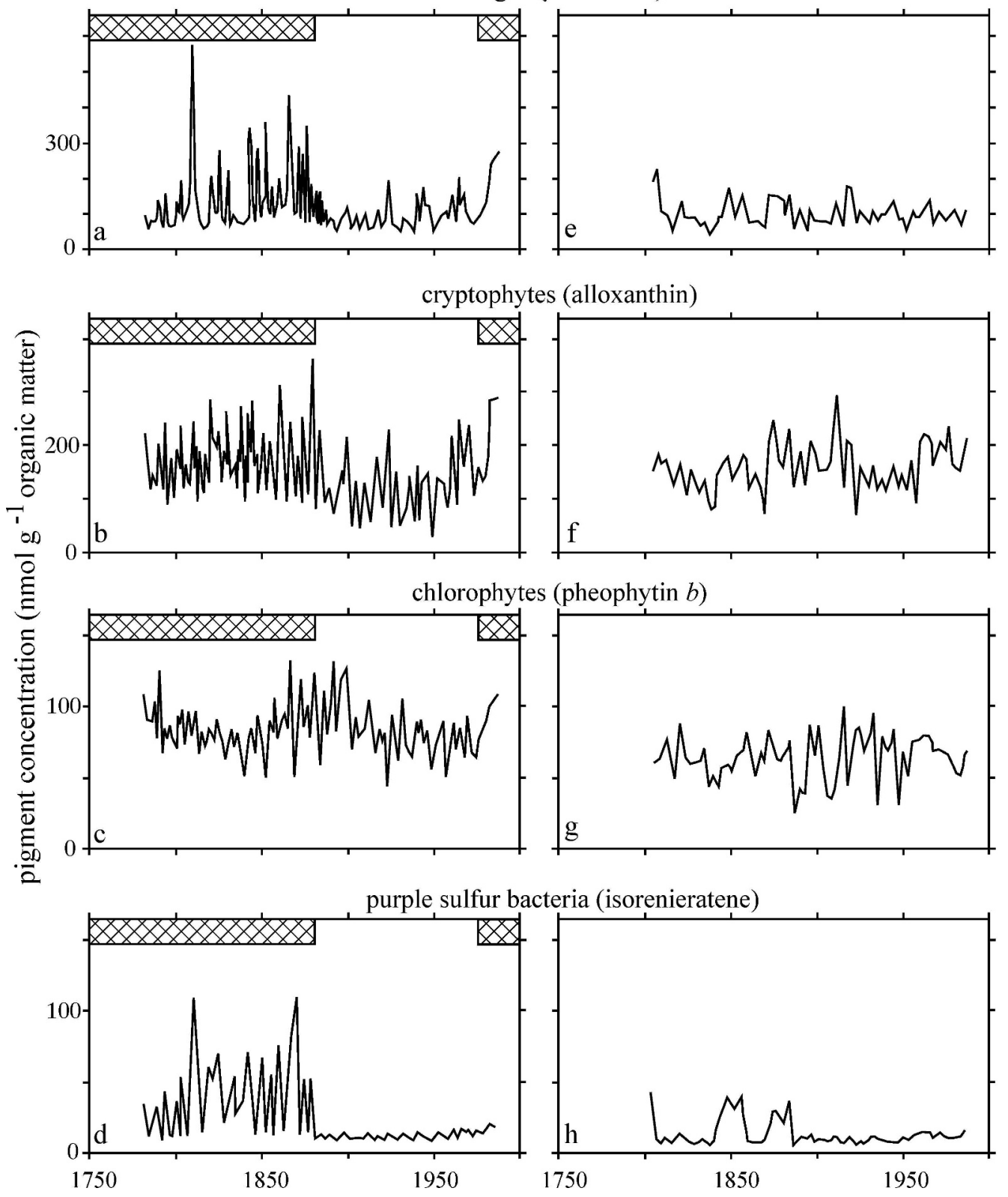
predominate in clear coastal Antarctic ponds because they contain effective photoprotective pigments lacking in other algae (Hodgson et al. 2004). Subsequent reconstruction of historical changes in algal production and community composition reveal that UVR influx was higher during the glacial period than during either the Holocene or the previous interglacial period, confirming that consistently high influx of $\mathrm{E}$ rather than other factors (salinity, nutrients, pond depth, DOM, ice cover) allows benthic cyanobacteria to predominate in algal assemblages.

Effects of mass influx - Climatic variability can influence lake ecosystems by altering the direct influx of water (path 3a), particles (path 3b), and solutes (path 3c) to a lake's surface or by changing indirect transfers of all mass components (paths $4 \mathrm{a}-\mathrm{c}$ ) through surface runoff and groundwater contributions (Table 1). As detailed by Blenckner (2005), catchments filter the effects of climate on lakes, primarily because local differences in geology, soils, vegetation, and morphology alter runoff and $m$ transfer from land to water. Because humans also exhibit strong effects on many direct and indirect $m$ pathways, most sedimentary studies of $m$ transfer have focused on sites with relatively little anthropogenic development (but see below). Furthermore, because changes in precipitation simultaneously alter indirect fluxes of solutes and particulate matter, paleolimnologists have tended to study the combined effects of precipitation on lake structure rather than attempt to isolate those of individual $m$ pathways.

Many paleolimnological analyses have investigated changes in lake level as an index of climatic effects on net $m$ transfer of water to lakes (Table 1, paths 1d, 3a, 4a). Changes in precipitation alter direct influx to the lake surface, catchment runoff, and groundwater inputs as well as losses due to surface and groundwater drainage, while variation in E influx can independently regulate $m$ loss via evaporation. When placed within this mass balance perspective, sedimentary analyses of large ancient lake ecosystems have demonstrated that massive changes in lake level occur as a result of variation in solar insolation, atmospheric circulation, and orbital characteristics, each operating on different time scales. For example, analysis of more than $80 \mathrm{yr}$ of meteorological and historical records from Lake Titicaca in the tropical Andes demonstrates that lake level has varied $\sim 7 \mathrm{~m}$ during the 20 th century, with lake levels decreasing during El Niño events, rising with $\mathrm{La}$ Niña episodes, and varying on decadal time scales because of long-term changes in sea-surface temperature (SST) and resultant atmospheric linkages in the tropical North

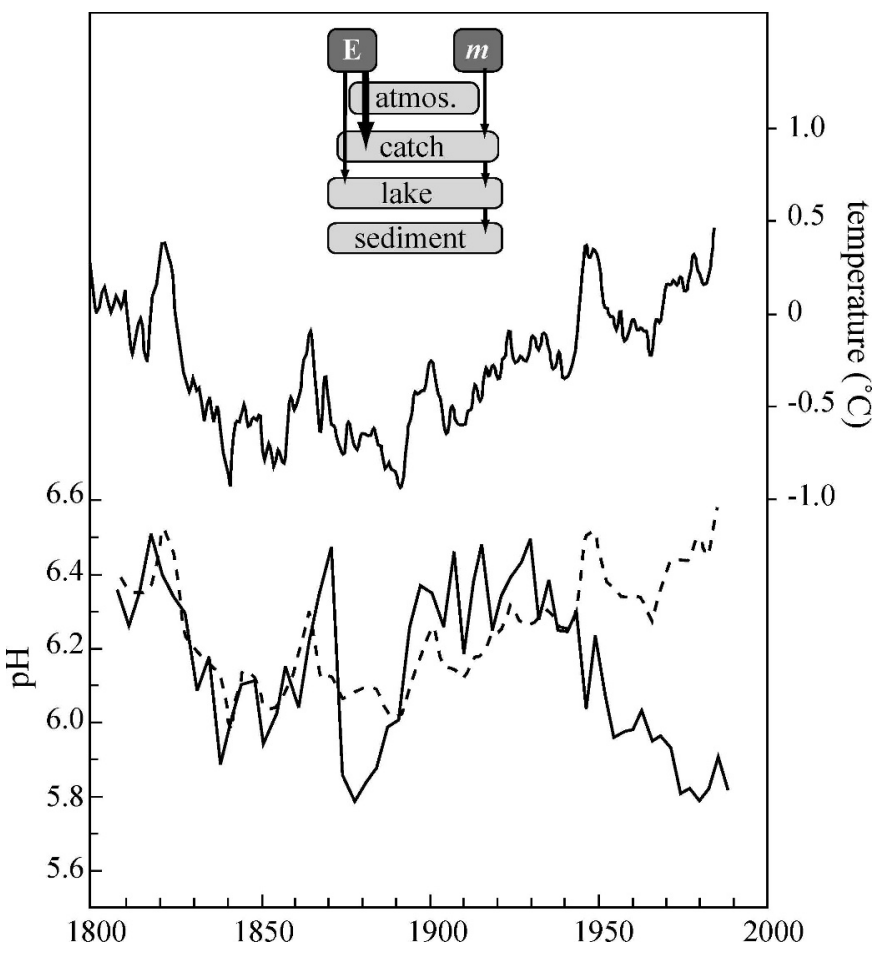

Fig. 4. Indirect effects of energy (E) influx from atmospheric heat on lake ecosystems via increased inorganic solute influx (modified from Psenner and Catalan 1994; Catalan and Psenner 2002). A combination of catchment mass balance, 200-yr monitoring records, and reconstruction of past $\mathrm{pH}$ using fossil diatoms revealed that changes in air temperature (upper solid line) alter the weathering of catchment bedrock, leading to changes in ionic mass influx that regulate the water-column $\mathrm{pH}$ of undisturbed lakes (lower dashed line). However, the indirect effects of E transfer as atmospheric heat on mass influx were overwhelmed by influx of solutes (protons) associated with acidic precipitation after 1900 in other lakes (lower solid line).

Atlantic Ocean (Baker et al. 2001b). Importantly, sedimentary analyses demonstrate that past lake levels have been much more variable than at present, with historical changes of about $20 \mathrm{~m}$ occurring at centennial and millennial scales because of the effects of abrupt cooling of the high-latitude North Atlantic Ocean and its effects on SST gradients in tropics (Baker et al. 2005). Even larger lake-level declines have resulted from variations in the South American summer monsoon driven by changes in orbital precession on 20,000-yr cycles $(75 \mathrm{~m})$ (Baker et al. 2001a,b), and orbital eccentricities at scales of $100,000 \mathrm{yr}(200 \mathrm{~m})$ (Fritz et al. 2007). Similar degrees of variability have been

Fig. 3. Effects of wind energy (E) on the physical structure and biological composition of small boreal forest lakes (modified from Scully et al. 2000). The west basin of Long Lake (a-d) is protected from wind by first growth (pre-1875) and second growth (post-1990) forests relative to wind-exposed east basin (e-h) and reference lakes Peter, Paul, and Tuesday (not shown). Clear-cut of first growth forest around 1880 increased wind friction to the protected western basin, increased mixing of the water column in fall, eliminated sedimentary laminae (hatched area, a-d), and reduced abundance of obligate anaerobic bacteria (d) as well as total algal abundance (a) as recorded by fossil pigments. No significant changes were recorded in the exposed eastern basin or reference lakes, demonstrating that changes in $\mathrm{E}$ influx from wind initiated ecosystem change. 

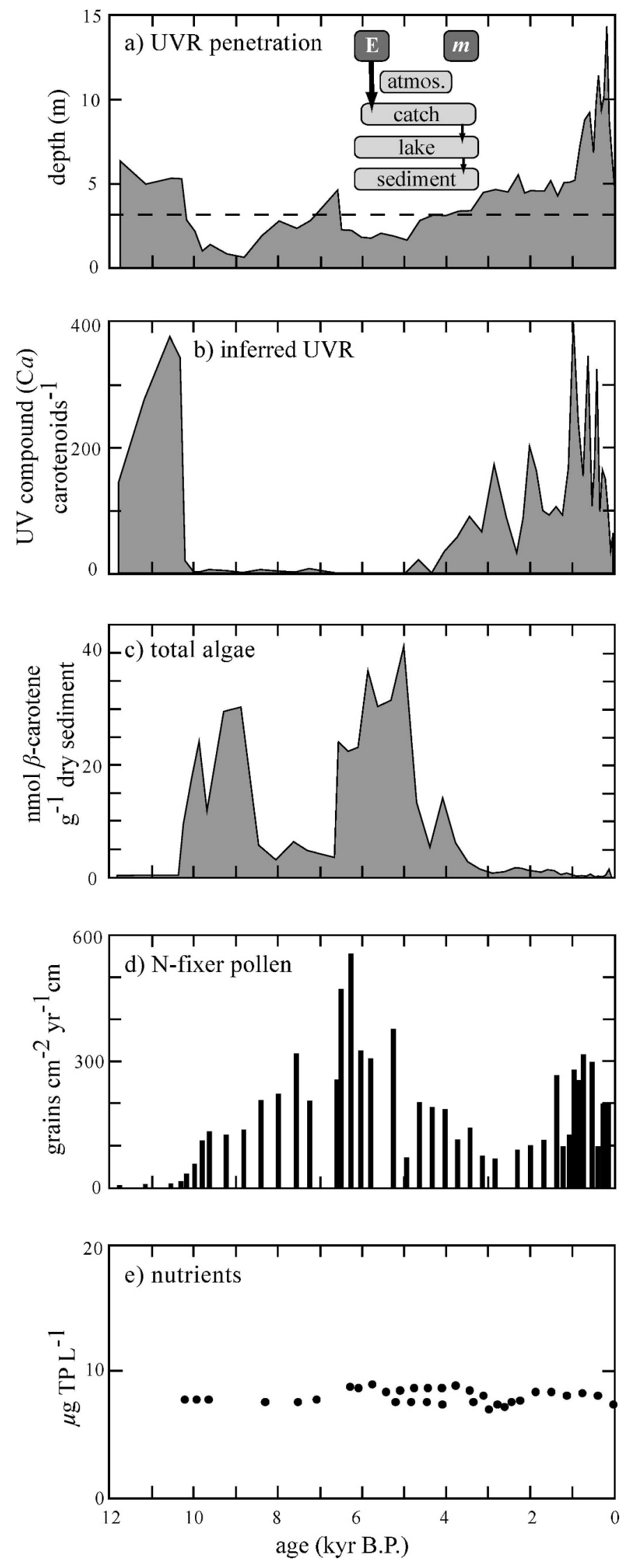

recorded for other ancient lakes including lakes Malawi (Scholz et al. 2007) and Victoria (Johnson et al. 2002) on the African continent and Lake Bonneville, the North American precursor to Utah's Great Salt Lake (Benson et al. 1990). Together, these studies suggest that changes in solar E influx and its effects on atmosphere-ocean linkages and $m$ transport overwhelm most limnologically studied sources of modern climatic variability (e.g., North Atlantic Oscillation, El Niño-Southern Oscillation, global warming, and so on).

Sedimentary studies reveal that lake response to changes in $m$ flux is mediated by hydrological setting at multiple temporal and spatial scales. For example, stable isotope and chemical mass balance models show that the termination of the last glacial period in the tropical Andes was characterized by elevated precipitation and an eightfold increase in outflow from Lake Titicaca relative to modern values (Cross et al. 2001). Increased export of water to downstream Salar de Uyuni allowed the lake's levels to rise to $\sim 140 \mathrm{~m}$, which dramatically expanded the lake surface area (Fritz et al. 2004b). Today, Salar de Uyuni is a dry basin despite relatively high levels of $m$ influx to both Lake Titicaca and Salar de Uyuni during recent millennia. Similarly, comparison of historical changes in net water balance (as fossil-reconstructed salinity) among lakes of the northern Great Plains reveals that both the magnitude and the direction of limnological response to common climate forcing vary among sites because of the differential importance of groundwater $m$ flux among regions and variable topographic position of lakes relative to local groundwater sources (Fritz et al. 2000; Laird et al. 2003; Fritz 2008). Unlike similar limnological conclusions based on whole-lake mass balances (Webster et al. 1996; Pham et al. 2008), sedimentary studies reveal that differences in lake response to climate may persist for centuries or may suddenly become coherent after long intervals of asynchrony. Taken together, these studies demonstrate that climatically induced changes in $m$ influx alter spatial synchrony among lakes (Pham et al. 2008, 2009) and suggest that evaluation of lake response to climatic variability should

$\leftarrow$

Fig. 5. Indirect effects of energy (E) influx from atmospheric heat on lake ecosystems via increased organic solute influx (modified from Leavitt et al. 2003). Analysis of sediments deposited during the past $12,000 \mathrm{yr}$ were used to reconstruct changes in past depth of UVR penetration estimated from (a) sedimentary organic matter content, (b) the exposure of algae to UVR inferred from fossil UVR-absorbing pigments, (c) past total algal abundance quantified from ubiquitous pigments, (d) change in the influx of $\mathrm{N}$ as deposition of fossil pollen from $\mathrm{N}_{2}$-fixing plants, and (e) changes in past phosphorous (P) content of lake water inferred from fossil diatoms. Crowfoot Lake, Canada, presently lies at treeline; however, increased regional temperature favored soil and vegetation development and influx of terrestrial photoprotective DOM to the lake during $\sim 10,000-4000 \mathrm{yr}$ в.P. This increase in DOM influx reduced UVR penetration, and, in combination with elevated $\mathrm{N}$ influx, allowed lake production to increase $\sim 10$-fold. Changes in algal biomass did not arise from variation in the $\mathrm{P}$ content of lake waters. 
explicitly evaluate the role of lake position in the hydrologic and topographic landscape.

Comparison of changes in hydrologic $m$ balances from contrasting lake districts confirms that modern climatic variability may be substantially different from that of the past while further suggesting that modern climate studies may provide an incomplete picture of the magnitude of limnological change associated with altered hydrologic $m$ flux in the future. For example, radiocarbon dating of past shorelines in lakes of western Greenland (Fig. 6) shows that modern lake elevations are the lowest of the past $\sim 6000 \mathrm{yr}$, with a decline of more than $6 \mathrm{~m}$ during the past $\sim 700 \mathrm{yr}$ (Aebly and Fritz 2009). Use of simulation models reveals that these patterns result mainly from changes in the seasonality of precipitation (proportion of summer vs. winter) rather than from variation in evaporative forcing. Furthermore, sedimentary reconstruction of changes in lake-water conductivity, algal communities, and primary production reveal substantial nonlinear relationships between changes in water level and the chemical and biological characteristics of the lake (McGowan et al. 2003, 2008). In the U.S. Rocky Mountains, diatom- and geochemically based reconstructions of lake level show that water levels have increased up to $6 \mathrm{~m}$ during the past $700 \mathrm{yr}$ because of changes in net water balance (Stevens et al. 2006). In addition, quantitative reconstruction of past lake volume using analysis of sedimentary diatoms shows that water levels in central Canadian lakes have fluctuated from 1 to $3 \mathrm{~m}$ during the past few millennia but that local basin levels can be up to $8 \mathrm{~m}$ higher than those $\sim 6000 \mathrm{yr}$ ago (Laird and Cumming 2008). In these and other cases (Korhola et al. 2005), present hydrologic balances can be fundamentally different from those inferred for recent millennia; however, the absence of consistent change in both the direction and the magnitude of $m$ flux change cautions investigators against extrapolating the effects of climate variability among lake districts.

To date, relatively few sedimentary studies have quantified influx of atmospheric particulate matter (Table 1, path 3b); however, ongoing limnological and fossil studies suggest that long-term changes in climate and land use can directly alter lake chemistry and ecology through deposition of atmospheric particles (Rogora et al. 2004; PulidoVillena et al. 2006). For example, Neff et al. (2008) used isotope ratios of $\mathrm{Sr}, \mathrm{Sm}$, and $\mathrm{Nd}$ in two lakes in the $\mathrm{San}$ Juan Mountains, U.S.A., to determine that more than $75 \%$ of the particulate influx is attributable to changes in regional land use and its effects on aeolian transport. In particular, deposition of atmospheric $\mathrm{Ca}, \mathrm{K}, \mathrm{Mg}$, and $\mathrm{P}$ increased over fivefold since around 1800, suggesting that long-term changes in lake production may arise from variation in land cover and anthropogenic activity. Similar effects are proposed to have operated over longer time frames, with changes in climate leading to continental-scale variation in atmospheric particle loads. For example, dust output from the Sahara presently varies between 400 and $70010^{12} \mathrm{~g} \mathrm{yr}^{-1}$, a value that accounts for $\sim 50 \%$ of the global atmospheric dust budget (Pulido-Villena et al. 2006). However, fossil studies suggest that particle loading to the

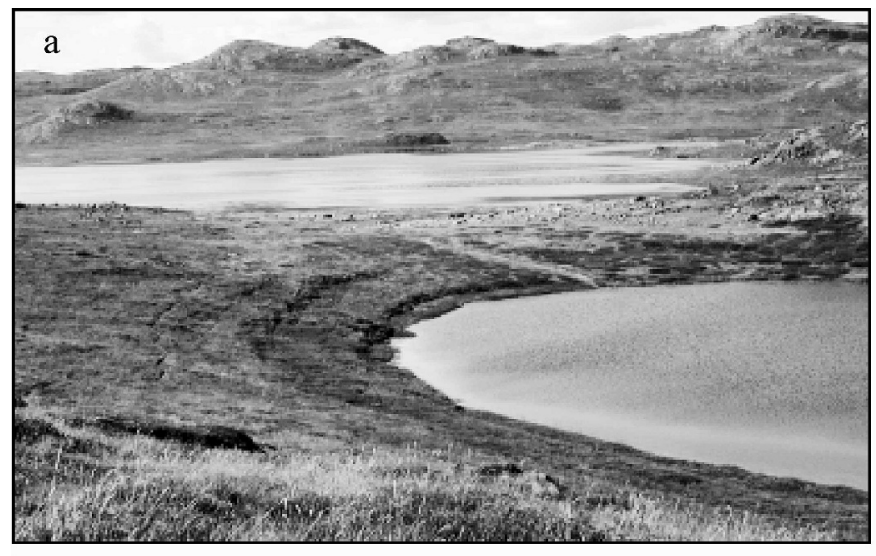

b

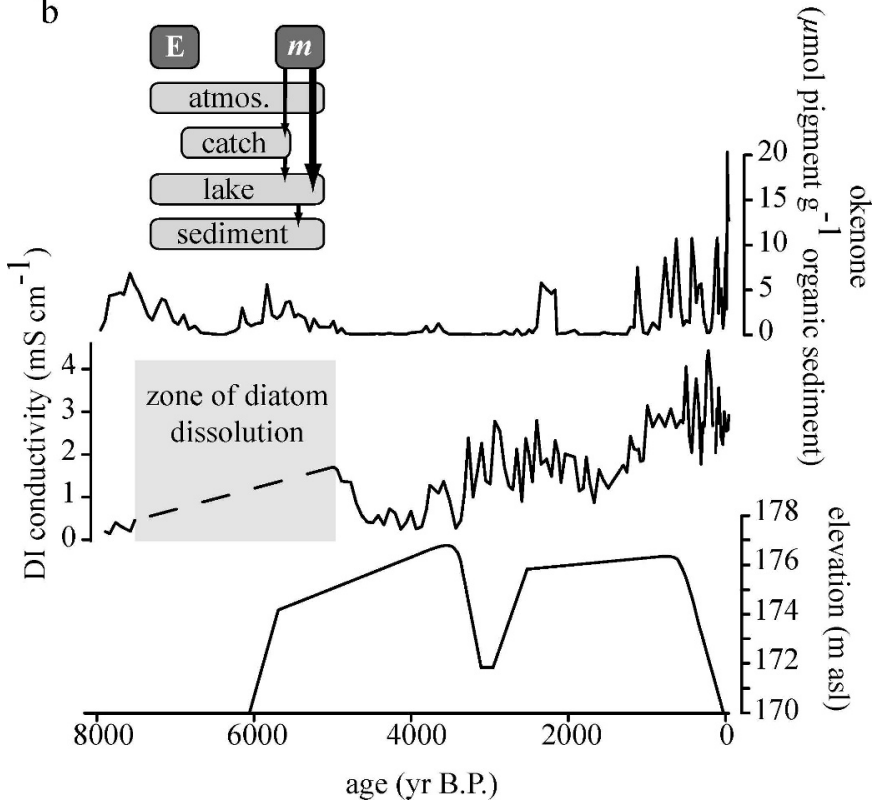

Fig. 6. Direct effects of changes in mass influx as precipitation on lake water balance and ecosystem structure (modified from McGowan et al. 2003; Aebly and Fritz 2009). (a) Analysis of the age of former lakeshores during ${ }^{14} \mathrm{C}$ shows that changes in water balance arising from variation in precipitation have reduced lake level $\sim 6 \mathrm{~m}$ during the past $700 \mathrm{yr}$ (bottom line in b). Reconstruction of historical changes in water conductivity using fossil diatom-based approaches (middle line in b) reveals that there is a nonlinear relationship between changes in lake level and water-column conductivity and that the combination of chemistry and morphology has complex effects on primary producers, including anaerobic purple sulfur bacteria, the populations of which are estimated from sedimentary concentrations of the biomarker pigment okenone (top line in b).

atmosphere (deflation) may have been substantially greater around $4300 \mathrm{yr}$ B.P., when desiccation of North Africa reduced vegetation cover and increased erosive activity of winds (Kröpelin et al. 2008). As speculated elsewhere, redeposition of Ca-rich Saharan dust may represent a significant influx of nutrients to alpine lakes, where weathering has previously depleted catchment stores of this element (Psenner 1999).

For more than $20 \mathrm{yr}$, paleolimnological studies have demonstrated how variation in atmospheric transport and 

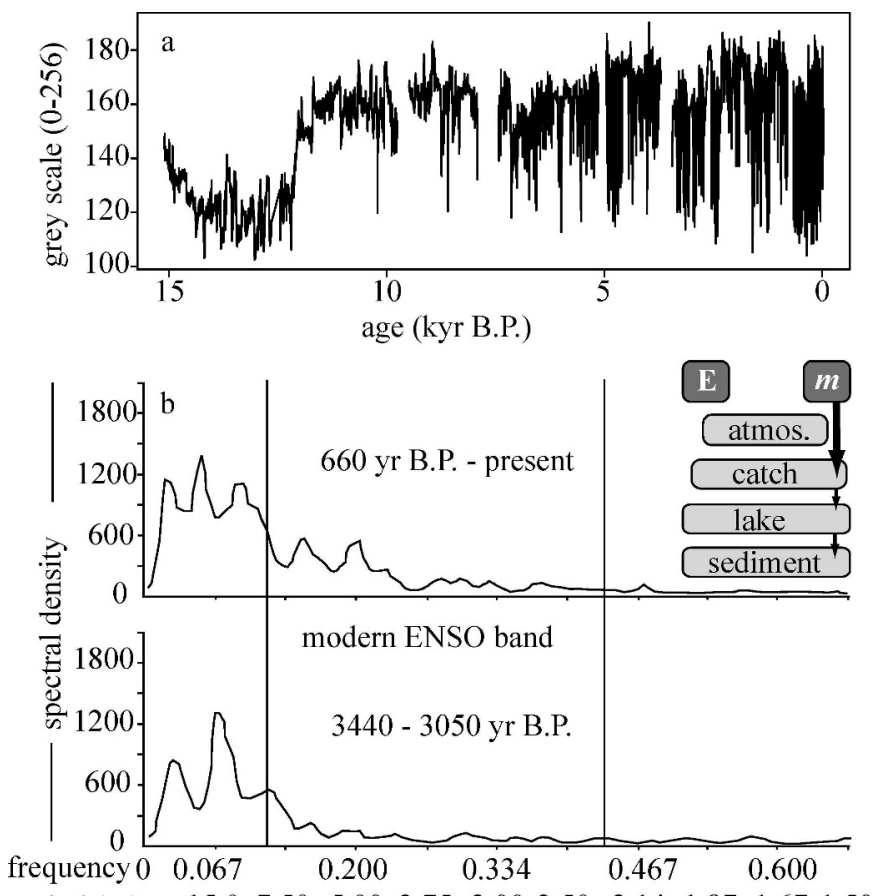

$\begin{array}{lllllllllll}\text { period }(\mathrm{yr}) & 15.0 & 7.50 & 5.00 & 3.75 & 3.00 & 2.50 & 2.14 & 1.87 & 1.67 & 1.50\end{array}$

Fig. 7. Indirect effects of mass influx as precipitation on particle influx to lakes (modified from Rodbell et al. 1999). (a) The gray-scale color of lake sediments was quantified for a period of $15,000 \mathrm{yr}$ in a lake in which sediment texture and composition are known to be controlled by variations in precipitation and catchment erosion of particles arising from changes in the ENSO climate system. Comparison of the spectral characteristics of component times series for the periods (b) 0-660 yr B.P. and (c) 3050-3440 yr B.P. reveals that the ENSO system has evolved during the Holocene and that high-frequency cycles (2-7 yr) are more common at present than in the past.

deposition of solutes (Table 1, path 3c) can regulate landscape patterns of lake biogeochemistry, productivity, and food web structure. During the 1980s, sedimentary analyses were instrumental in showing that deposition of industrially derived $\mathrm{HNO}_{3}$ and $\mathrm{H}_{2} \mathrm{SO}_{4}$ caused continental patterns of lake-water acidification (Battarbee et al. 1990), toxic Al contamination (Cumming et al. 1992), and fundamental changes in predator-prey regimes (Uutala and Smol 1996), while fossil analyses since that time have quantified the direction, rate, and extent of lake recovery following solute diversion (Smol et al. 1998). More recently, comparative analysis of stable isotope signatures of $\mathrm{N}$ in atmospheric pollutants, lake water, bulk sediments, and individual fossils has demonstrated that industrial pollution can fertilize oligotrophic mountain lakes and restructure algal communities when patterns of atmospheric circulation lead to the direct deposition of $\mathrm{NO}_{\mathrm{x}}$ in lakes (Wolfe et al. 2001). Importantly, these and many other examples demonstrate that the extent of recent changes in lake chemistry and community composition can exceed those recorded for previous centuries, thereby suggesting that effects of modern climate forcing may be obscured in lakes in which influx of solutes from the atmosphere is altered by human activities.
Analysis of temporal changes in $m$ accumulation in lake sediments reveals that cyclic and discontinuous changes in climate systems regulate the transfer of particulate $m$ from catchments to lakes indirectly by changing hydrologic runoff (Table 1, path 4b). In instances where geochemical analyses show that the mineral component of sediments can be attributed uniquely to catchment sources, changes in $m$ burial rates can be used to reconstruct historical changes in catchment erosion. For example, Rodbell et al. (1999) measured changes in the color and fine structure of annually laminated sediments in a tropical lake in which particle influx is controlled by mineral erosion of a steep catchment to demonstrate that modern variations in $m$ influx exhibited the same time-series characteristics as precipitation events caused by the El Niño-Southern Oscillation (ENSO) climate system (Fig. 7). Furthermore, by comparing the spectral characteristics of shorter component time intervals within the 15,000 -yr continuous record, investigators suggested that the magnitude and periodicity of the ENSO system have varied during the Holocene. Such long-term climatic evolution is likely to be invisible to modern limnological analyses (Magnuson 1990), but its inclusion in predictive models may be critical to forecasting the effects of global warming on climate and lake systems (MacKay et al. 2009).

Changes in solute $m$ influx arising from variation in catchment runoff (Table 1, path 4c) have been shown by retrospective analyses to influence the physical and biological structure of unproductive lakes on diverse time scales. For example, modern lake surveys demonstrate routinely that the depth of UVR penetration into lakes is regulated by the concentration of DOM derived from terrestrial runoff (Morris et al. 1995). Under these conditions, declines in precipitation can reduce influx of photoprotective DOM and are expected to reduce primary production by increasing algal exposure to damaging irradiance. This hypothesis has been tested by comparing dendroclimatic estimates of changes in regional precipitation during the past $500 \mathrm{yr}$ (Case and MacDonald 1995) with quantitative estimates of past UVR penetration and algal production using sedimentary algal pigments in two lakes of the eastern Rocky Mountains (Leavitt et al. 1997). Analyses reveal that UVR penetration increased $\sim 10$-fold at both sites only during severe regional droughts (around 1850-1900) known from tree-ring and instrumental time series and that the magnitude of historical change in UVR stress on algae is greater than that arising from current anthropogenic ozone depletion. Furthermore, because differences in total algal abundance in these lakes are more strongly correlated with UVR penetration than with nutrient status (Leavitt et al. 2003), these paleolimnological studies infer that future declines in precipitation and solute $m$ influx may expose many presently DOM-replete boreal lakes to highly damaging levels of UVR.

Reconstruction of historical changes in water-column concentrations of allochthonous elements also illustrates that regional water chemistry may vary coherently among lake regions because of millennial-scale changes in influx of inorganic solutes (Fig. 8). For example, a survey of 30 lakes in northern Wisconsin reveals strong linear relationships $\left(r^{2}\right.$ 
a) modern lake sediments (30 lakes)

b) Klondike Lake

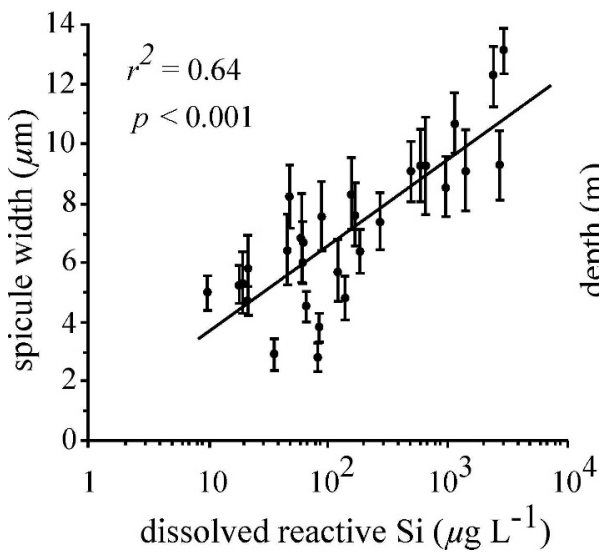

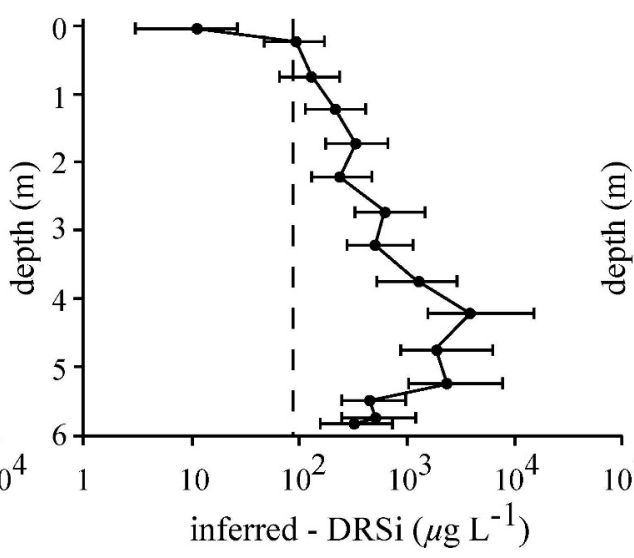

c) Fallison Lake

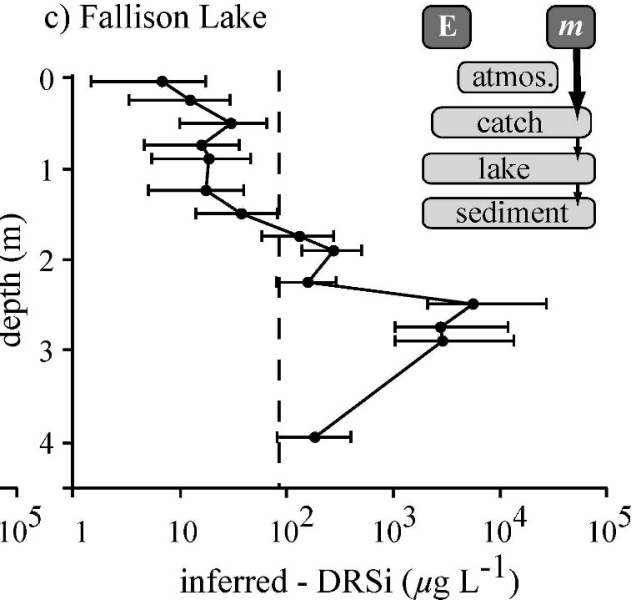

Fig. 8. Evidence of changes in the magnitude of mass influx independent of climate (modified from Kratz et al. 1991). (a) Survey of 30 lakes in Wisconsin reveals a strong positive correlation between the silica ( $\mathrm{Si}$ ) content of lake water and the thickness of living and subfossil sponge spicules in the lake. (b, c) Application of this regression equation to sedimentary changes in fossil spicule thickness in eight lakes reveals that regional Si concentrations have declined substantially during the Holocene. Comparison of this pattern with insights from mass balance budgets and fossil reconstructions of regional climate and vegetation change suggests that Si depletion arose from loss of weatherable material from within the lake catchments, which in turn reduced Si contributions to local groundwater.

$=0.64)$ between observed concentrations of dissolved reactive $\mathrm{Si}$ and the width of subfossil sponge spicules (Kratz et al. 1991). When this regression was applied to historical changes in spicule morphology in eight regional lakes, fossil reconstructions demonstrate that dissolved Si concentrations have declined an average of 35 -fold during the Holocene. Unexpectedly, comparison of time series with vegetation histories reconstructed from fossil pollen analyses suggests that declines in Si content are unlikely to have arisen from climate change or regional vegetation cover. Instead, declines in solute influx appear to result from loss of easily weathered material from within the catchment, leading to declines in $\mathrm{Si}$ influx to lakes via groundwater. Similar depletion of catchment sources of inorganic solutes by weathering is known to have occurred commonly during the Holocene, both from paleolimnological analyses (Reasoner et al. 1994) and from surveys of lakes along modern chronoseries (Fritz et al. 2004a), suggesting that lake response to a given climatic event will vary with the age of the catchment and its weathering history (Blenckner 2005).

Complex interactions of $E$ and $m$ influx-Perhaps the greatest challenge to forecasting the effects of future climate change on lakes is that relatively little is known of the regulatory hierarchy between diverse $\mathrm{E}$ and $m$ influx pathways and how these interactions may be affected by human activities. To date, analysis of whole-lake $m$ and $\mathrm{E}$ budgets suggests that effects of $\mathrm{E}$ on lake structure are overwhelmed by changes in $m$ influx in lakes of central North America (Pham et al. 2008, 2009; Dröscher et al. 2009). Unfortunately, it remains unclear whether these patterns arise because influx of $m$ has an intrinsically greater effect than that of $\mathrm{E}$ or whether the range of variation in $m$ influx (e.g., precipitation) is much greater than that associated with E influx (atmospheric heat, solar irradiance). Resolution of this issue is essential to improve forecasts of future climate effects because anthropogenic activities most often alter indirect paths of $m$ influx to lakes. Although relatively few paleolimnological studies have quantified potential interactions among $\mathrm{E}$ and $m$ transfers, evidence to date is consistent with the presence of a discrete regulatory hierarchy that may result in nonlinear and hysteretic effects of individual climatic pathways on ecosystem structure and function.

Comparison of long-term monitoring records with highly resolved sedimentary analyses suggests that effects of direct $\mathrm{E}$ influx may be overwhelmed by concomitant changes in $m$ transfer in lakes experiencing eutrophication or other anthropogenic disturbances (Fig. 9). For example, direct observation reveals that interannual changes in ice cover are highly synchronous over much of the Canadian prairies and that ice cover has declined more than $30 \mathrm{~d}$ since 1870 (Magnuson et al. 2000). Despite this strong temporal gradient, statistical comparison of fossil time series of diatom species composition, algal production, and gross community composition (fossil pigments of diatoms, cryptophytes, cyanobacteria, and so on) with century-long measurements of environmental change reveals that climatically induced changes in E and $m$ influx explained only $5-15 \%$ of total variation in algal communities of eight lakes during the 20th century (Hall et al. 1999). Instead, changes in $m$ transfer arising from agricultural development and urbanization explained fourfold more variation than did climate alone, particularly when anthropogenic activities were considered together. Furthermore, rather than suggesting that climate had little effect on lakes, this variance partitioning analysis (VPA) suggests that meteorological variability may act in conjunction with human activities to regulate $m$ transfer effects on ecosystem structure and function.

Analysis of coeval climate, limnological, and fossil time series also demonstrates that meteorological variability during the 20th century has differential effects on producer 


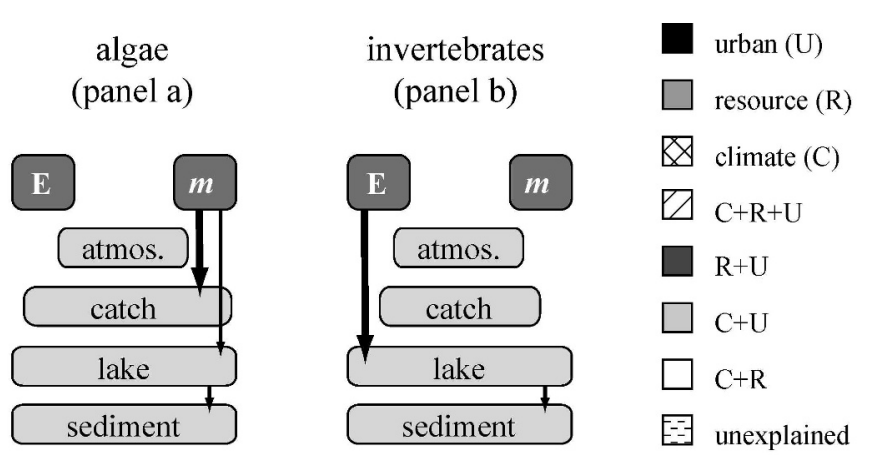

a
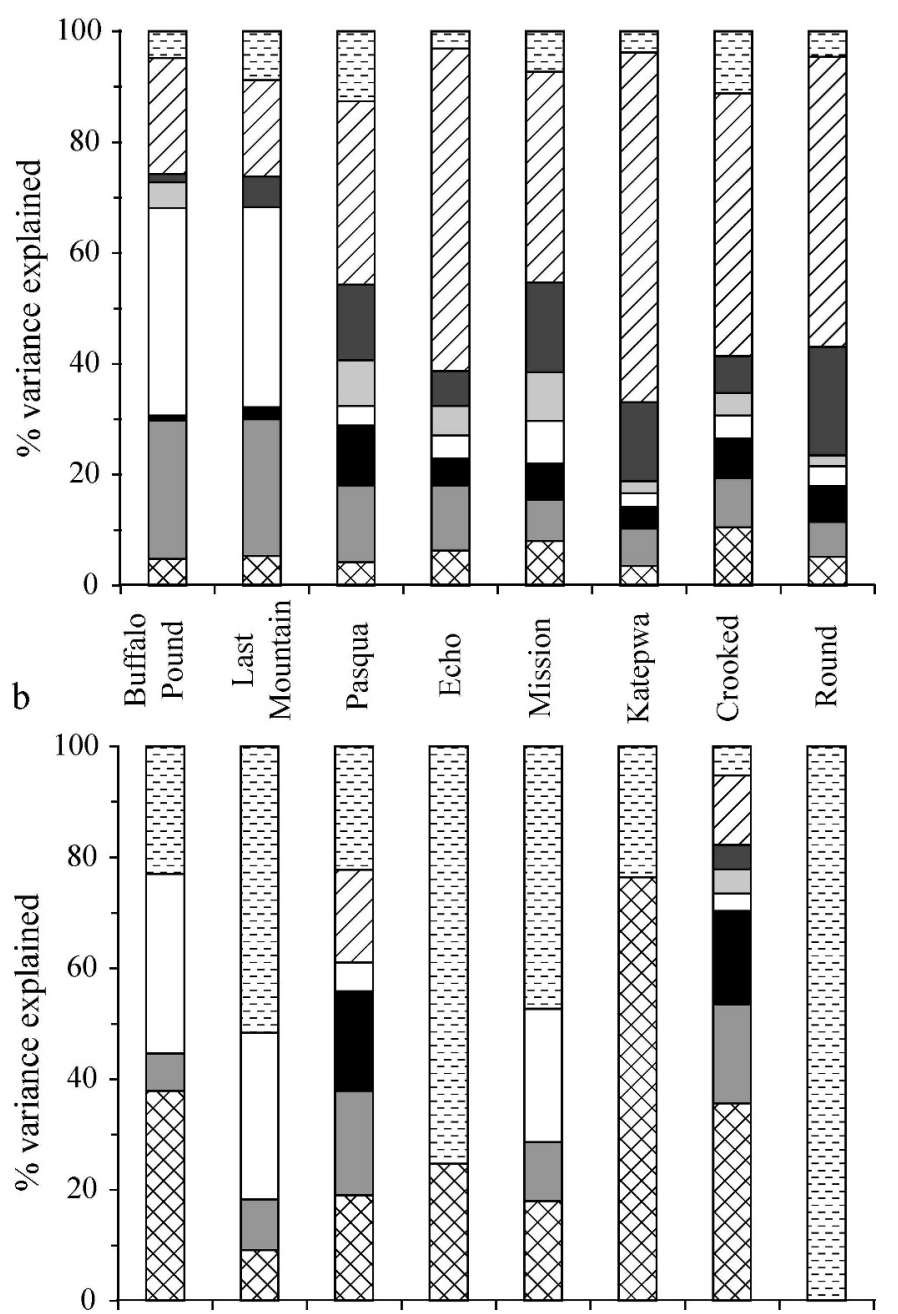

Fig. 9. Paleolimnological evidence that energy and mass transfer pathways associated with climate can be overwhelmed by change in $m$ influx associated with land use and urbanization (modified from Hall et al. 1999; Quinlan et al. 2002; P. R. Leavitt unpubl.). VPA was used to quantify the statistical relationship between measured changes in 80-yr-long time series of climate (C), resource use (R), urbanization ( $\mathrm{U})$, and fossil records of changes in (a) the abundance and composition of algae and (b) benthic invertebrates in eight lakes of the Qu'Appelle River catchment, Canada. Overall, the direct effects of climate variability on algae were overwhelmed by concomitant changes in mass influx from farms and cities, with climatic change explaining only $5-15 \%$ of variation in past algal assemblages. In contrast, changes in and consumer populations. As described above, historical variation in $\mathrm{E}$ and $m$ influx explained only $6.0 \pm 2.3 \%$ of concomitant changes in algal production and composition since 1930 (Fig. 9). In contrast, climatic variation alone explained up to $76 \%$ of variance in benthic invertebrate communities during the same period (Quinlan et al. 2002), although the average ( \pm SD) response of zoobenthos varied greatly among sites (mean $\pm \mathrm{SD} ; 27.6 \pm 23.4 \%)$. Similarly, analysis of 100-1000-yr-long responses of diatom and chironomid communities to temperature declines during the Younger Dryas period (Birks et al. 2000), early Holocene warming (Bigler et al. 2002), and mid-Holocene climatic change (8.2-kyr event) also shows that climate has differential effects on individual components of aquatic food webs (see Adrian et al. 2009). Overall, fossil evidence that temperature has a more pronounced effect on consumers than on producers is consistent with the metabolic theory of ecology (Brown et al. 2004) and may arise because heterotrophic respiration is thought to be more intrinsically sensitive (higher $\mathrm{Q}_{10}$ ) to changes in temperature than is algal growth. However, sedimentary analyses also suggest that there is a high degree of spatial variability in food web response to climatic variability, possibly reflecting local differences in catchment development (Blenckner 2005) and its effect on the ability of individual organisms to complete their life cycles (e.g., terrestrial habitats for adult aquatic invertebrates).

Undoubtedly the greatest impediment to identifying the effects of ongoing climate change on lakes is the observation that human activities often induce unprecedented changes in $m$ influx to lakes that can overwhelm other regulatory mechanisms. For example, numerous paleolimnological studies show that changes in terrestrial vegetation and land use arising from deforestation and agriculture fundamentally alter $m$ influx to lakes on time scales ranging from years to millennia (reviewed in Dearing and Jones 2003). Effects on deforestation of eastern North America by ancestral European settlers 200 yr ago appear highly similar to those recorded for sites in northwestern Europe and Central America thousands of years ago (Davis 1976; Anselmetti et al. 2007). In all cases, rates of $m$ accumulation in lake sediments increase dramatically (up to 20-fold) with forest clearance, although the magnitude of erosion and $m$ transfer to lakes also depends on complex interactions between precipitation, geology, soils, and the precise use of land following forest clearance (Dearing and Jones 2003). In instances where erosive influx is sustained, lakes can exhibit rapid infilling, reduced basin depth, and expansions of macrophyte populations that alter habitat

$\leftarrow$

resource use and urbanization accounted for threefold more variation in past algal communities. High degrees of factor interaction $(\mathrm{C}+\mathrm{R}, \mathrm{C}+\mathrm{U}, \mathrm{C}+\mathrm{R}+\mathrm{U})$ suggest that human activities also modify climate effects on lakes. Finally, VPA also reveals that climate has a stronger effect on invertebrates than on algae in these lakes, with particularly marked direct effects of changes in temperature on benthic chironomids (mean 27.6\% explained variation). 


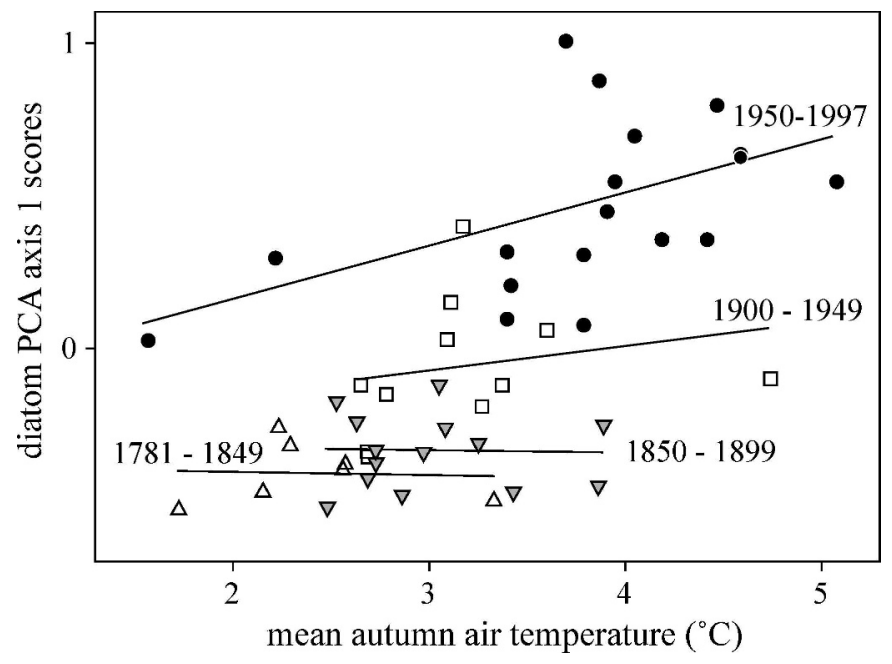

Fig. 10. Paleolimnological evidence that algal response to a fixed temperature change varies through time, possibly because of historical changes in other energy $(\mathrm{E})$ and mass $(m)$ influxes (modified from Catalan et al. 2002a). Historical changes in diatom species assemblages in a Pyrenees lake from 1780 to the present were summarized using a PCA score for the first PCA axis (PCA 1). Variations in the PCA 1 score were compared during several historical intervals in which mean fall air temperature varied at least $2^{\circ} \mathrm{C}$. Prior to 1900 , diatom species composition varied similarly in response to changes in air temperature (lines parallel and slope low); however, following 1900, algal communities evolved in different directions and at different rates (slopes) despite similar magnitudes of temperature forcing. This analysis suggests that lakes experience a hysteretic effect in which lake resilience to climate varies through time as a function of other changes in E and $m$ influxes.

and food web structure (Rasmussen and Anderson 2005). Similarly, fossil analyses often reveal that sustained agricultural activity causes lake eutrophication by elevating inputs of nutrients from crop fertilizers, plant processing, and livestock activities (Fritz 1989; Anderson et al. 1995). Importantly, most paleolimnological studies demonstrate that these sustained ecosystem transformations can also alter lake structure and function for thousands of years (Bradshaw et al. 2005), thereby completely masking the effects of climatic variation on aquatic ecosystems.

Recent sedimentary studies suggest that interactions among $\mathrm{E}$ and $m$ influx pathways may lead to ecosystem hysteresis in which lake response to climate varies through time (Fig. 10). For example, by comparing meteorological records and fossil time series of diatom community composition in lakes of the Spanish Pyrenees, Catalan et al. (2002b) revealed that the magnitude and nature of diatom community response to a standard atmospheric warming of $2-3^{\circ} \mathrm{C}$ has not been constant through time. Overall, global warming in this region has increased mean autumn air temperatures by $\sim 4^{\circ} \mathrm{C}$; however, this long-term trend is also composed of oscillations and excursions of similar magnitude but shorter temporal duration. Principal components analysis (PCA) of the entire time series reveals that diatom community response to documented temperature change (summarized as PCA axis 1 scores) was similar during the first and second half of the 19th century but that algal communities have evolved along different pathways during both halves of the 20th century. Although it is uncertain whether differences among centuries reflect progressive changes in the influence of other $\mathrm{E}$ or $m$ influx pathways, this study reveals that both lake resistance and resilience to environmental change have decreased since 1900. Such reduced resilience favors discontinuous transitions among ecosystem states (e.g., alternate stable states) and can lead to nonlinear responses of lakes to constant climatic forcing.

\section{Future challenges and opportunities}

General circulation models forecast unprecedented increases in the mean and variance of global temperature over the next $100 \mathrm{yr}$ (Field et al. 2007); however, atmospheric warming is only one of at least 11 pathways by which climate can influence lake structure and function (Table 1). As demonstrated above, changes in $m$ influx arising from variation in precipitation are equally potent controls of lake ecosystems both because of intrinsically high spatial and temporal variability (Pham et al. 2008) and because $m$ transfer is strongly affected by human activities within the catchment. Unfortunately, changes in hydrologic $m$ transfer have proven more difficult to forecast other than that the magnitude of temporal variation in precipitation is likely to increase with increased atmospheric energy (Field et al. 2007). Furthermore, human populations are expected to increase by three billion people in the next $40 \mathrm{yr}$, leading to an additional $2-10$-fold increase in solute and particulate $m$ transfer to lakes in inhabited catchments (Millennium Ecosystem Assessment 2005). In many instances, insufficient time may remain to quantify the complex interactions between $\mathrm{E}$ and $m$ pathways using standard monitoring and experimental approaches. Instead, we propose that investigators use the $\mathrm{Em}$ flux framework to explicitly integrate paleolimnological approaches into an ecosystem-level, process-based understanding of the relative effects of climate and humans on lakes. Below we suggest means to overcome obstacles and to embrace the challenges inherent in this integration.

In principle, paleolimnological techniques can be applied to any issue in which the passage of time plays a central role in understanding the regulation of ecosystem structure or function. However, to fully exploit the power of the retrospective approach, future studies will need to adopt an experimental structure in which lakes are selected a priori to test well-defined hypotheses. For example, sedimentary studies often provide unambiguous mechanistic insights when lakes have been selected to contrast landscape position along a defined gradient of environment change or disturbance (Figs. 3, 9) or when studies select lakes of differing characteristics (shallow vs. deep, surface vs. groundwater hydrology, and so on) that can be used to contrast basin response to a single forcing mechanism (Anderson et al. 2008; Fritz 2008). As in experimental research, the use of reference or "control" ecosystems has proven essential to distinguish among causal mechanisms. Similarly, regulatory mechanisms have been identified more clearly when fossil studies use diverse geochemical 
and biological response variables, each with well-defined but alternate responses to $\mathrm{E}$ and $m$ influx pathways, and when there exists sophisticated understanding of the mechanisms by which fossil records are formed (Cuddington and Leavitt 1999; Stone and Fritz 2006). However, although great advances have been made during the past $30 \mathrm{yr}$ (Last and Smol 2001), there remain substantial gaps in our understanding of the ways in which atmosphere, catchment, and lakes act as information filters that convert causal time series into fossil records (Blenckner 2005).

As with any branch of ecosystem science, mechanistic interpretation of sedimentary records is most robust when sedimentary records are compared statistically with coeval time series of many potentially causal agents. In this regard, paleolimnological studies have been most scientifically compelling when fossil time series are compared with contemporaneous instrumental records using advanced statistical approaches such as VPA, a canonical technique that summarizes the overall degree of covariance among predictor and response variables (Lotter and Birks 1997; Quinlan et al. 2002). Unfortunately, such monitoring records are rarely available for remote locations or for studies that span more than a few hundred years. To address this shortcoming, new sedimentary indicators are being developed to generate independent records of past $\mathrm{E}$ and $m$ flux, including use of organic compounds (e.g., alkenones) to reconstruct past water-column temperature (Zink et al. 2001; Powers et al. 2004) and stable H isotopes in lipids to quantify historical changes in water influx (Huang et al. 2004). Similarly, new time-series approaches such as dynamic linear models (Cottingham et al. 2000), multispecies autoregressive models (Hampton et al. 2006), wavelet analysis (Keitt 2008), and multivariate analysis of variance homogeneity (Anderson 2006) have been used to identify the mechanisms causing ecosystem variability, while the next generation of additive mixed models shows great promise for identifying how the importance of $E$ and $m$ flux can change independently through time (Simpson and Anderson 2009).

By simultaneously capturing information on past climate as well as population, community, and ecosystem attributes of lakes, analysis of sedimentary records also offers investigators the unique opportunity to test ecological theory pertaining to climate and other environmental controls. For example, Rusak et al. (2004) measured changes in diatom species richness and production in two lakes for $2000 \mathrm{yr}$ to demonstrate that the negative diversity-function relationships predicted from modern ecological theory were apparent only during historic intervals that lacked droughts. Similarly, McGowan et al. (2005) used fossil time series to demonstrate that shifts between turbid and clear-water states of shallow lakes arise from the combined effects of climate and eutrophication but found no clear evidence that these "alternative" states were capable of existing under similar environmental conditions. Likewise, analysis of the sediments of a high Arctic lake shows that dramatic reductions in Daphnia and chironomid abundance during the mid-Holocene warm period (Bennike et al. 2008) are more consistent with changes in hydrologic connectivity, colonization by fish, and predator-prey regimes (Jeppesen et al. 2003) than with the direct effects of $\mathrm{E}$ influx. Together, these and other studies demonstrate both that paleoecological studies can benefit from the explicit tests of modern theory and that retrospective studies are capable of generating new insights for the development of predictive theory.

In conclusion, we believe that advances in the understanding of climate and other stressors on lakes will arise most effectively from the synergistic integration of paleolimnology techniques into a common theoretical and methodological framework rather than by enforcing preexisting disciplinary distinctions. In particular, we believe that sedimentary studies provide unique temporal and spatial insights to limnology but that retrospective analyses could benefit from a more explicit theoretical approach. Similarly, although process-oriented studies are ideal for identifying the mechanism by which climate or humans affect lakes, improved temporal and spatial perspectives should help limnologists develop a hierarchical understanding of potential regulatory processes. In this regard, we believe that the Em flux framework represents an important first step in the development of a common dialogue among disciplines.

\section{Acknowledgments}

Manuscript preparation was supported by the Canada Research Chair program, Natural Science and Engineering Research Council of Canada (NSERC), Canada Foundation for Innovation, the Province of Saskatchewan, the National Science Foundation (grant EAR-0602154), the University of Regina, and the Office of Research of the University of Nebraska. We thank two reviewers for insightful comments.

\section{References}

Adrian, R., And others. 2009. Lakes as sentinels of climate change. Limnol. Oceanogr. 54: 2283-2297.

Aebly, F., And S. C. Fritz. 2009. The paleohydrology of West Greenland for the past 8000 years. Holocene 19: 91104.

Anderson, M. J. 2006. Distance-based tests for homogeneity of multivariate dispersions. Biometrics 62: 245-253.

Anderson, N. J., K. Broderson, D. B. Ryves, S. McGowan, L. S. Johansson, E. JePpesen, And M. J. Leng. 2008. Climate versus in-lake processes as controls on the development of community structure in a low-arctic (South-West Greenland). Ecosystems 11: 307-324.

- H. Bugmann, J. A. Dearing, and M.-J. Gaillard. 2006. Linking palaeoenvironmental data and models to understand the past and to predict the future. Trends Ecol. Evol. 21: 698-704.

- I. Renberg, and U. Segerstrom. 1995. Diatom production responses to the development of early agriculture in a boreal forest lake-catchment (Kassjön, northern Sweden). J. Ecol. 83: 809-822.

Anselmetti, F. S., D. A. Hodell, D. Ariztegui, M. Brenner, AND M. F. RosenmeIER. 2007. Quantification of soil erosion rates related to ancient Maya deforestation. Geology 35: 915-918.

Baker, P. A., S. C. Fritz, J. Garland, and E. Ekdahl. 2005. Holocene hydrologic variation at Lake Titicaca, Bolivia/Peru and its relationship to North Atlantic climate variation. J. Quat. Sci. 20: 655-662. 
, C. A. Rigsby, G. O. Seltzer, S. C. Fritz, T. K. Lowenstein, N. Bacher, And C. Veliz. 2001a. Tropical climate changes at millennial and orbital timescales in the Bolivian Altiplano. Nature 409: 698-701.

—, AND OTHERS. 2001b. The history of South American tropical precipitation for the past 25,000 years. Science 291: 640-643.

Battarbee, R. W. 2000. Palaeolimnological approaches to climate change, with special regard to the biological record. Quat. Sci. Rev. 19: 107-124.

, N. J. Anderson, E. Jeppesen, and P. R. Leavitt. 2005. Combining palaeolimnological and limnological approaches in assessing lake ecosystem response to nutrient reduction. Freshw. Biol. 50: 1772-1780.

—, J. Mason, I. Renberg, and J. F. Talling. 1990. Paleolimnology and lake acidification: Proceedings of a Royal Society discussion meeting held on 25 August 1989. Cambridge Univ. Press.

Bennike, O., AND others. 2008. Late Quarternary environmental and cultural changes in the Wollaston Forland region, North East Greenland. Adv. Ecol. Res. 40: 45-79.

Benson, L. V., And others. 1990. Chronology of expansion and contraction of four Great Basin lake systems during the past 35,000 years. Palaeogeogr. Palaeoclimatol. Palaeoecol. 78: 241-286.

Bigler, C., I. Larocque, S. M. Peglar, H. J. B. Birks, and R. I. Hall. 2002. Quantitative multiproxy assessment of long-term patterns of Holocene environmental change from a small lake near Abisko, northern Sweden. Holocene 12: 481-496.

Birks, H. H., R. W. Battarbee, and H. J. B. Birks. 2000. The development of the aquatic ecosystem at Krakenes Lake, western Norway, during the late-glacial and early-Holocenea synthesis. J. Paleolimnol. 23: 91-114.

BlencKNeR, T. 2005. A conceptual model of climate-related effects on lake ecosystems. Hydrobiologia 533: 1-14.

- - AND OTHERS. 2007. Large-scale climatic signatures in lakes across Europe: A meta-analysis. Global Change Biol. 13: $1314-1326$.

Bonsal, B. R., T. D. Prowse, C. R. Duguay, and M. P. Lacroix. 2006. Impacts of large-scale teleconnections on freshwater-ice break/freeze-up dates over Canada. J. Hydrol. 330: 340-353.

Bracht, B., J. R. Stone, and S. C. Fritz. 2008. A diatom record of late-Holocene climate variability in the northern Rocky Mountains. Quat. Int. 188: 149-155.

Bradbury, J. P. 1988. A climatic limnologic model of diatom succession for palaeolimnological interpretation of varved sediments at Elk Lake, Minnesota. J. Paleolimnol. 1: 115-131.

Bradley, R. S. 1999. Paleoclimatology. 2nd ed. Harcourt Academic Press.

Bradshaw, E. G., P. Rasmussen, H. Nielsen, and N. J. Anderson. 2005. Mid- to late-Holocene land-use change and lake development at Dallund So, Denmark: Trends in lake primary production as reflected by algal and macrophyte remains. Holocene 15: 1130-1142.

Brown, J. H., J. F. Gillooly, A. P. Allen, V. M. Savage, and D. B. West. 2004. Toward a metabolic theory of ecology. Ecology 85: 1771-1789.

CARPenter, S. R. [ED.]. 1999. Complex interactions in lake communities. Springer-Verlag.

Carpenter, S. R., and P. R. Leavitt. 1991. Temporal variation in a paleolimnological record arising from a trophic cascade. Ecology 72: 277-285.

Case, R. A., and G. M. Macdonald. 1995. A dendroclimatic reconstruction of annual precipitation on the western Canadian prairies since A.D. 1505 from Pinus flexilis James. Quat. Res. 44: 267-275.
CAtalan, J., AND others. 2002a. Lake Redó ecosystem response to an increasing warming in the Pyrenees during the twentieth century. J. Paleolimnol. 28: 129-145.

— AND . 2002b. Seasonal ecosystem variability in remote mountain lakes: Implications for detecting climatic signals in sediment records. J. Paleolimnol. 28: 25-46.

Cottingham, K. L., J. A. Rusak, and P. R. Leavitt. 2000. Increased ecosystem variability and reduced predictability following fertilisation: Evidence from palaeolimnology. Ecol. Lett. 3: 340-348.

Cross, S. L., P. A. Baker, G. O. Seltzer, S. C. Fritz, and R. B. DunBAR. 2001. Late Quaternary climate and hydrology of tropical South America inferred from isotopic and chemical model of Lake Titicaca, Bolivia and Peru. Quat. Res. 56: $1-9$.

Cuddington, K., and P. R. Leavitt. 1999. An individual-based model of pigment flux in lakes: Implications for organic biogeochemistry and paleoecology. Can. J. Fish. Aquat. Sci. 56: $1964-1977$.

Cumming, B. F., AND others. 1992. How much acidification has occurred in Adirondack region lakes (New York, USA) since pre-industrial times? Can. J. Fish. Aquat. Sci. 49: 128-141.

DAvis, M. B. 1976. Erosion rates and land-use history in southern Michigan. Environ. Conserv. 3: 139-148.

Dearing, J. A., And R. T. Jones. 2003. Coupling temporal and spatial dimensions of global sediment flux through lake and marine sediment records. Glob. Planet. Change 39: 147168.

Diffenbaugh, N. S., M. Ashfaq, B. Shuman, J. W. Williams, AND P. Bartlein. 2006. Summer aridity in the United States: Response to mid-Holocene changes in insolation and sea surface temperature. Geophys. Res. Lett. 33: L22712, doi:10.1029/2006GL028012.

Dröscher, I., A. Patoine, K. Finlay, and P. R. Leavitt. 2009. Climate control of the spring clear-water phase through the transfer of energy and mass to lakes. Limnol. Oceanogr. 54: 2469-2480.

Field, C. B., AND others. 2007. North America, p. 617-652. In M. L. Parry, O. F. Canziani, J. P. Palutikof, P. J. van der Linden and C. E. Hanson [eds.], Climate change 2007: Impacts, adaptation and vulnerability. Contribution of working group II to the fourth assessment report of the intergovernmental panel on climate change. Cambridge Univ. Press.

FriTZ, S. C. 1989. Lake development and limnological response to prehistoric and historic land-use in Diss, Norfolk, U.K. J. Ecol. 77: 182-202.

. 2008. Deciphering climatic history from lake sediments. J. Paleolimnol. 39: 5-16.

- P. A. Baker, G. O. Seltzer, A. P. Ballantyne, P. M. TAPIA, H. Cheng, And R. L. Edwards. 2007. Quaternary glaciation and hydrologic variation in the South American tropics as reconstructed from the Lake Titicaca drilling project. Quat. Res. 68: 410-420.

, E. Ito, Z. Yu, K. R. Laird, and D. R. Engstrom. 2000. Hydrologic variation in the northern Great Plains during the last two millennia. Quat. Res. 53: 175-184.

, S. Juggins, And D. R. Engstrom. 2004a. Patterns of early lake evolution in boreal landscapes: A comparison of stratigraphic inferences with a modern chronosequence in Glacier Bay, Alaska. Holocene 14: 828-840.

, AND OTHERS. 2004b. Hydrologic variation during the last 170,000 years in the southern hemisphere tropics of South America. Quat. Res. 61: 95-104.

HÅkAnson, L., And M. Jansson. 1983. Principles of lake sedimentology. Springer-Verlag. 
Hall, R. I., P. R. Leavitt, R. Quinlan, A. S. Dixit, and J. P. SMOL. 1999. Effects of agriculture, urbanization, and climate on water quality in the northern Great Plains. Limnol. Oceanogr. 44: 739-756.

Hampton, S. E., M. D. Scheuerell, and D. E. Schindler. 2006. Coalescence in the Lake Washington story: Interaction strengths in a planktonic food web. Limnol. Oceanogr. 51: 2042-2051.

Hodgson, D. A., W. Vyverman, E. Verleyen, P. R. Leavitt, K. Sabbe, A. H. Squier, and B. J. Keely. 2005. Late Pleistocene record of elevated UV radiation in an Antarctic lake. Earth Planet. Sci. Lett. 236: 765-772.

- AND OTHERs. 2004. Environmental factors influencing the pigment composition in in situ aquatic microbial communities under the Antarctic ozone hole. Aquat. Microb. Ecol. 37: 247-263.

Huang, Y., B. Shuman, Y. Wang, and T. Webb III. 2004. Hydrogen isotope ratios of individual lipids in lake sediments as novel tracers of climatic and environmental change: A surface sediment test. J. Paleolimnol. 31: 363-375.

Hurrell, J. W. 1995. Decadal trends in the North Atlantic Oscillation: Regional temperatures and precipitation. Science 269: 676-679.

Interlandi, S. J., S. S. Kilham, and E. C. Theriot. 1999. Responses of phytoplankton to varied resource availability in large lakes of the Greater Yellowstone Ecosystem. Limnol. Oceanogr. 44: 668-682.

JEPPESEN, E., AND OTHERs. 2003. The impact of nutrient state and lake depth on top-down control in the pelagic zone of lakes: Study of 466 lakes from the temperate zone to the Arctic. Ecosystems 6: 313-325.

Johnson, T. C., E. T. Brown, J. McManus, S. Barry, P. Barker, AND F. GASSE. 2002. A high-resolution paleoclimate record spanning the past 25,000 years in Southern East Africa. Science 296: 113-114.

Keatley, B. E., M. S. V. Douglas, and J. P. Smol. 2008. Prolonged ice cover dampens diatom community responses to recent climatic change in high Arctic lakes. Arct. Antarct. Alp. Res. 40: 364-372.

KeItT, T. H. 2008. Coherent ecological dynamics induced by large-scale disturbance. Nature 454: 331-334.

Keller, W. 2007. Implications of climate warming for Boreal Shield lakes: A review and synthesis. Env. Rev. 15: 99-112.

Korhola, A., M. Tikkanen, and J. Weckström. 2005. Quantification of Holocene lake-level changes in Finnish Lapland using a cladocera-lake depth transfer model. J. Paleolimnol. 34: $175-190$.

Kratz, T. K., T. M. Frost, J. E. Elias, and R. B. Cook. 1991. Reconstruction of a regional, 12,000-yr silica decline in lakes by means of fossil sponge spicules. Limnol. Oceanogr. 36: $1244-1249$

Kröpelin, S., AND others. 2008. Climate-driven ecosystem succession in the Sahara: The past 6000 years. Science 320: $765-768$.

LAird, K. R., And B. F. Cumming. 2008. Reconstruction of Holocene lake level from diatoms, chrysophytes and organic matter in a drainage lake from the Experimental Lakes Area. Quat. Res. 69: 292-305.

- AND OTHERS. 2003. Lake sediments record large-scale shifts in moisture regimes across the northern Prairies of North America during the past two millennia. Proc. Natl. Acad. Sci. USA 100: 2483-2488.

Last, W. M. And J. P. Smol [Eds.]. 2001. Tracking environmental change using lake sediments: Developments in paleoenvironmental research. V. 1 and 2. Kluwer Academic Press.
Leavitt, P. R., S. R. Carpenter, and J. F. Kitchell. 1989. Whole-lake experiments: The annual record of fossil pigments and zooplankton. Limnol. Oceanogr. 34: 700717.

, B. F. Cumming, J. P. Smol, M. Reasoner, R. Pienitz, AND D. A. Hodgson. 2003. Climatic control of UV radiation effects on lakes. Limnol. Oceanogr. 48: 20622069.

, AND D. A. Hodgson. 2001. Sedimentary pigments, p. 295-326. In J. P. Smol, H. J. B. Birks and W. M. Last [eds.], Tracking environmental change using lake sediments. Kluwer Academic Publishers.

, R. D. Vinebrooke, D. B. Donald, J. P. Smol, and D. W. SChindler. 1997. Past ultraviolet radiation environments in lakes derived from fossil pigments. Nature 388: 457-459.

LotTer, A. F., AND H. J. B. BiRKs. 1997. The separation of the influences of nutrients and climate on the varve time-series of Baldeggersee, Switzerland. Aquat. Sci. 59: 362-375.

MacKay, M. D., AND others. 2009. Modeling lakes and reservoirs in the climate system. Limnol. Oceanogr. 54: 2315-2329.

Magnuson, J. J. 1990. Long-term ecological research and the invisible present. BioScience 40: 495-501.

- B. J. Benson, and T. K. Kratz. 1990. Temporal coherence in the limnology of a suite of lakes in Wisconsin, U.S.A. Freshw. Biol. 23: 145-159.

- AND OTHERS. 2000. Historical trends in lake and river ice cover in the Northern Hemisphere. Science 289: 17431746.

Mantua, N. J., S. Hare, Y. Zhang, J. M. Wallace, and R. C. FRANCIS. 1997. A Pacific interdecadal climate oscillation with impacts on salmon production. Bull. Am. Meteorol. Soc. 78: 1069-1080.

McGowan, S., R. K. Juhler, And N. J. Anderson. 2008. Autotrophic response to lake age, conductivity and temperature in two west Greenland lakes. J. Paleolimnol. 39: 301-317.

, P. R. Leavitt, R. I. Hall, N. J. Anderson, E. Jeppesen, AND B. V. OdgaARd. 2005. Controls of algal abundance and community composition during ecosystem state change. Ecology 86: 2200-2211.

- D. B. Reeves, and N. J. Anderson. 2003. Holocene records of effective precipitation in west Greenland. Holocene 13: $239-249$.

Millennium Ecosystem Assessment. 2005. Ecosystems and human well-being: Current state and trends. V. 1. Island Press.

Morris, D. P., AND others. 1995. The attenuation of solar UV radiation in lakes and the role of dissolved organic carbon. Limnol. Oceanogr. 40: 1381-1391.

NefF, J. C., AND others. 2008. Increasing eolian dust deposition in the western United States linked to human activity. Nat Geosci. 1: 189-195.

Pham, S. V., P. R. Leavitt, S. McGowan, and P. Peres-Neto. 2008. Spatial variability of climate and land-use effects on lakes of the northern Great Plains. Limnol. Oceanogr. 53: $728-742$

$\longrightarrow,-$, B. Wissel, AND L. I. WassenaAr. 2009. Spatial and temporal variability of prairie lake hydrology as revealed using stable isotopes of hydrogen and oxygen. Limnol. Oceanogr. 54: 101-118.

Pienitz, R., And W. F. Vincent. 2000. Effect of climate change relative to ozone depletion on UV exposure in subarctic lakes. Nature 404: 481-487. 
Powers, L. A., J. P. Werne, T. C. Johnson, E. C. Hopmans, J. S. Sinninghe Damste, and S. Schouten. 2004. Crenarchaeotal membrane lipids in lake sediments: A new paleotemperature proxy for continental paleoclimate reconstruction. Geology 32: 613-616.

PSENNER, R. 1999. Living in a dusty world: Airborne dust as a key factor for alpine lakes. Water Air Soil Pollut. 112: 217-227.

- And J. Catalan. 1994. Chemical composition of lakes in crystalline basins: A combination of atmospheric deposition geologic backgrounds, biological activity and human action, p. 255-314. In R. Margalef [ed.], Limnology now: A paradigm of planetary problems. Elsevier.

- AND R. Schmidt. 1992. Climate-driven $\mathrm{pH}$ control of remote alpine lakes and effects of acid deposition. Nature 356: 781-783.

Pulido-Villena, , E. I. Reche, and R. Morales-Baquero. 2006. Significance of atmospheric inputs of calcium over the southwestern Mediterranean region: High mountain lakes as tools for detection. Glob. Biogeochem. Cycle 20: GB2012, doi:10.1029/2005GB002662.

Quinlan, R., P. R. Leavitt, A. S. Dixit, R. I. Hall, and J. P. SMOL. 2002. Landscape effects of climate, agriculture and urbanization on benthic invertebrate communities of Canadian prairie lakes. Limnol. Oceanogr. 47: 378-391.

Quiring, S. M., AND T. N. PAPAKyriakou. 2005. Characterizing the spatial and temporal variability of June-July moisture conditions in the Canadian prairies. Int. J. Climatol. 25: $117-138$.

Rasmussen, P., and N. J. Anderson. 2005. Natural and anthropogenic forcing of aquatic macrophyte development in a shallow Danish lake during the last 7000 years. J. Biogeogr. 32: 1993-2005.

Reasoner, M. A., G. Osborn, and N. W. Rutter. 1994. Age of the Crowfoot advance in Canadian Rocky Mountains: A glacial event coeval with the Younger Dryas Oscillation. Geology 22: 439-442.

Rodbell, D. T., G. O. Seltzer, D. M. Anderson, M. B. Авbott, D. B. Enfield, And J. H. Newman. 1999. An 15,000-year record of El Niño-driven alleviation in southwestern Ecuador. Science 283: 516-520.

Rogora, M., R. Mosello, and A. Marchetto. 2004. Long-term trends in the chemistry of atmospheric deposition in northwestern Italy: The role of increasing Saharan dust deposition. Tellus Ser. B Chem. Phys. Meteorol. 56: 426-434.

Rühland, K., A. M. Paterson, And J. P. Smol. 2008. Hemispheric-scale patterns of climate-related shifts in planktonic diatoms from North American and European lakes. Glob. Change Biol. 14: 2740-2754.

Rusak, J. A., P. R. Leavitt, S. McGowan, G. Chen, O. G. Olson, S. Wunsum, And B. F. Cumming. 2004. Millennial-scale relationships of diatom species richness and production in two prairie lakes. Limnol. Oceanogr. 49: 1290-1299.

$\longrightarrow$, N. D. Yan, AND K. M. Somers. 2008. Regional climatic drivers of synchronous zooplankton dynamics in northtemperate lakes. Can. J. Fish. Aquat. Sci. 65: 878-889.

Schindler, D. W. 2001. The cumulative effects of climate warming and other human stresses on Canadian freshwaters in the new millennium. Can. J. Fish. Aquat. Sci. 58: 18-29.

2009. Lakes as sentinels and integrators for the effects of climate change on watersheds, airsheds, and landscapes. Limnol. Oceanogr. 54: 2349-2358.

Scholz, C. A., AND others. 2007. East African megadroughts between 135-75 kyr ago and bearing on early-modern human origins. Proc. Natl. Acad. Sci. USA 104: 1641616421 .
Scully, N. M., P. R. Leavitt, and S. R. Carpenter. 2000. Century-long effects of forest harvest on the physical structure and autotrophic community of a small temperate lake. Can. J. Fish. Aquat. Sci. (suppl. 2) 57: 50-59.

Simpson, G. L., And N. J. Anderson. 2009. Deciphering the effect of climate change and separating the influence of confounding factors in sediment core records using additive models. Limnol. Oceanogr. 54: 2529-2541.

Smol, J. P., And B. F. Cumming. 2000. Tracking long-term changes in climate using algal indictors in lake sediments. J. Phycol. 36: 986-1011.

Smol, JP, H. J. B. BiRks And W. M. LAst [Eds.]. 2001. Tracking environmental change using lake sediments: Developments in paleoenvironmental research. V. 3. Kluwer Academic Press.

Smol, J. P., B. F. Cumming, A. S. Dixit, and S. S. Dixit. 1998. Tracking recovery patterns in acidified lakes: A paleolimnological perspective. Restor. Ecol. 6: 318-326.

Sommaruga-Wograth, S., K. A. Koinig, R. Schmidt, R. Sommaruga, R. Tessadri, and R. Psenner. 1997. Temperature effects on the acidity of remote alpine lakes. Nature 387: 63-67.

Stevens, L. R., J. R. Stone, J. Campbell, and S. C. Fritz. 2006. A 2200-yr record of hydrologic variability from Foy Lake, Montana, USA, inferred from diatom and geochemical data. Quat. Res. 65: 264-274.

Stone, J. R., And S. C. Fritz. 2004. Three-dimensional modeling of lacustrine diatom habitat areas: Improving paleolimnological interpretation of planktic:benthic ratios. Limnol. Oceanogr. 49: $1540-1548$.

, AND —. 2006. Multidecadal drought and Holocene climate instability in the Rocky Mountains. Geology 34: 409-412.

Tranvik, L. J., AND OTHERs. 2009. Lakes and reservoirs as regulators of carbon cycling and climate. Limnol. Oceanogr. 54: 2298-2314.

Trenberth, K. E., and J. W. Hurrell. 1994. Decadal atmosphere-ocean variations in the Pacific. Clim. Dyn. 9: 303 319.

Uutala, A. J., And J. P. Smol. 1996. Paleolimnological reconstructions of long-term changes in fisheries status in Sudbury area lakes. Can. J. Fish. Aquat. Sci. 53: 174 180.

Vinebrooke, R. D., And P. R. LeavitT. 1998. Direct and interactive effects of allochthonous dissolved organic matter, inorganic nutrients, and ultraviolet radiation on an alpine littoral food web. Limnol. Oceanogr. 43: 1065-1081.

- AND 2005. Mountain lakes as indicators of the cumulative impacts of ultraviolet radiation and other environmental stressors, p. 497-510. In U. Huber, H. K. M. Bugmann and M. A. Reasoner [eds.], Global change and mountain regions - an overview of current knowledge. Springer.

Walker, A., B. Goodison, M. Davey, and D. Olson. 1995. Atlas of southern Canadian Prairies winter snow cover from satellite passive microwave data: November 1978 to March 1986. Atmospheric Environment Service, Environment Canada.

Webster, K. E., T. K. Kratz, C. J. Bowser, and J. J. Magnuson. 1996. The influence of landscape position on lake chemical responses to drought in northern Wisconsin. Limnol. Oceanogr. 41: 977-984.

Whitfield, P. H., K. Bodtker, and A. J. Cannon. 2002. Recent variations in seasonality of temperature and precipitation in Canada, 1976-1995. Int. J. Climatol. 22: 1617-1644. 
Williams, D. F., J. Peck, E. B. Karabanov, A. A. Prokopenko, V. Kreachinsky, J. King, and M. I. Kuzmin. 1997. Lake Baikal record of continental climate response to orbital insolation during the past 5 million years. Science 278: $1114-1116$

Wolfe, A. P., J. S. Baron, And R. J. Cornett. 2001. Anthropogenic nitrogen deposition induces rapid ecological changes in alpine lakes of the Colorado Front Range (USA). J. Paleolimnol. 25: 1-7.

Woodhouse, C. A., AND J. T. Overpeck. 1998. 2000 years of drought variability in the central United States. Bull. Am. Meteorol. Soc. 79: 2693-2714.
Zink, K.-G., D. Leythaeuser, M. Melkonian, and L. Schwark. 2001. Temperature dependency of long-chain alkenone distributions in recent to fossil limnic sediments and in lake waters. Geochim. Cosmochim. Acta 65: 253-265.

Associate editors: Warwick F. Vincent and John P. Smol

Received: 02 November 2008 Accepted: 18 March 2009 Amended: 26 March 2009 